Rumah sakit sebagai salah satu fasilitas pelayanan kesehatan memiliki peran strategis dalam peningkatan pelayanan bermutu dan terjangkau oleh masyarakat. Upaya manajemen rumah sakit memperbaiki dan meningkatkan kualitas pelayanan keperawatan melalui penilaian kinerja perawat. Masalah yang muncul dalam penilaian kinerja perawat adalah kurangnya unsur caring dalam proses penilaian kinerjanya.

Buku ini berusaha menjelaskan tentang sistem penilaian kinerja perawat pelaksana berbasis caring sebagai panduan Manajer Keperawatan Rumah Sakit dalam pengambilan keputusan untuk meningkatkan mutu pelayanan keperawatan. Di dalam buku ini disajikan Alat penilaian kinerja perawat berdasarkan caring yang bertujuan untuk mengukur aktivitas caring perawat sehingga mampu meningkatkan kepuasan kinerja perawat dan mutu asuhan keperawatan kepada klien. Penulis berharap, buku ini dapat dijadikan sebagai sumber referensi akademisi dan praktisi keperawatan khususnya bidang manajemen dan administrasi keperawatan.

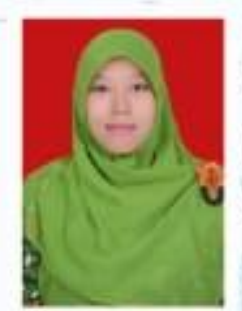

Evita Muslima Isnanda Putri, S. Kep., Ns., M. Kep lahir di Bojonegoro tahun 1989; menyelesaikan sekolah menengah di SMA Negeri 1 Bojonegoro, Lulus Pendidikan Sarjana Keperawatan dan Profesi Ners di Fakultas Keperawatan Universitas Airlangga pada tahun 2012. Lulus S2 Magister Keperawatan di Fakultas Keperawatan Universitas Airlangga pada tahun 2016. Saat ini penulis melaksanakan tugas sebagai dosen Tetap Program Studi DIII Keperawatan STIKES Rajekwesi Bojonegoro, dan menjadi Wakil Ketua 3 bidang kemahasiswaan, alumni \& kerjasama STIKES Rajekwesi Bojonegoro.
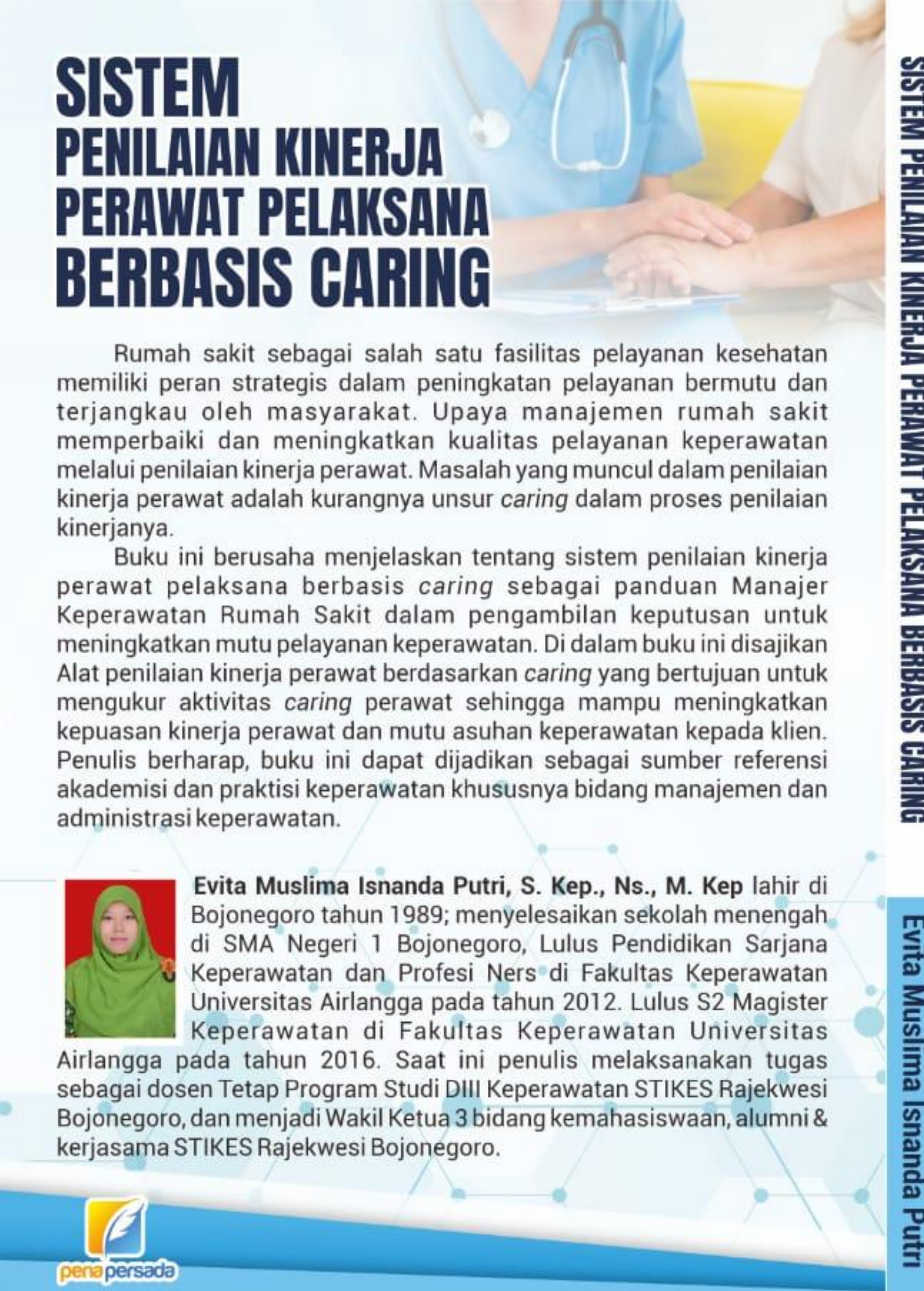

Evita Muslima Isnanda Putri

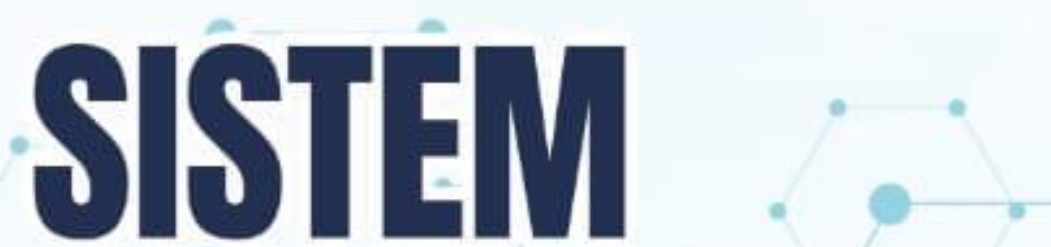
PENILAIAN KINERJA PERAWAT PELAKSANA BERBASIS CARING 


\section{SISTEM PENILAIAN KINERJA PERAWAT PELAKSANA BERBASIS CARING}

EVITA MUSLIMA ISNANDA PUTRI

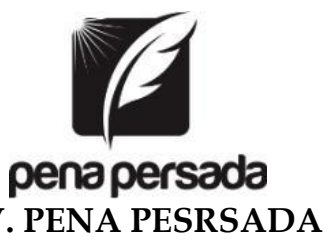




\title{
SISTEM PENILAIAN KINERJA PERAWAT PELAKSANA
} BERBASIS CARING

\author{
Penulis : \\ Evita Muslima Isnanda Putri \\ Editor: \\ Wiwit Kurniawan \\ ISBN :978-623-6688-47-2 \\ Design Cover : \\ Retnani Nur Briliant \\ Layout : \\ Hasnah Aulia

\section{Penerbit CV. Pena Persada \\ Redaksi :} \\ Tengah \\ Email : penerbit.penapersada@gmail.com \\ Website : penapersada.com \\ Phone : (0281) 7771388 \\ Anggota IKAPI \\ All right reserved \\ Cetakan pertama : 2020
}

Jl. Gerilya No. 292 Purwokerto Selatan, Kab. Banyumas Jawa

Hak cipta dilindungi oleh undang-undang.

Dilarang memperbanyak karya tulis ini dalam bentuk dan cara apapun tanpa ijin penerbit 


\section{KATA PENGANTAR}

Alhamdulillah, segala puji syukur penulis panjatkan kehadirat Allah SWT, atas segala karunia dan ridho-NYA, sehingga buku dengan judul "Sistem Penilaian Kinerja Perawat Pelaksana Berbasis Caring" ini dapat diselesaikan.

Dalam buku ini dijelaskan tentang sistem penilaian kinerja perawat pelaksana berbasis caring sebagai panduan Manajer Keperawatan Rumah Sakit dalam pengambilan keputusan untuk meningkatkan mutu pelayanan keperawatan. Sistem penilaian kinerja perawat pelaksana berbasis caring ini dapat dijadikan sebagai sumber referensi akademisi dan praktisi keperawatan khususnya bidang manajemen dan administrasi keperawatan.

Dengan keterbatasan pengalaman, pengetahuan maupun pustaka yang ditinjau, penulis menyadari bahwa buku ini masih banyak kekurangan dan perlu pengembangan lebih lanjut agar benar-benar bermanfaat. Oleh sebab itu, penulis sangat mengharapkan kritik dan saran agar buku ini lebih sempurna serta sebagai masukan bagi penulis untuk penelitian dan penulisan karya ilmiah di masa yang akan datang. Akhir kata, penulis berharap buku ini memberikan manfaat bagi kita semua terutama untuk pengembangan ilmu keperawatan.

Bojonegoro, September 2020

Penulis 


\section{DAFTAR ISI}

KATA PENGANTAR ............................................................... iii

DAFTAR ISI ...................................................................... iv

BAB I PENDAHULUAN …................................................. 1

BAB II KINERJA
A. Pengertian Kinerja ........................................................ 2
B. Teori Kinerja ....................................................................... 3

BAB III PENILAIAN KINERJA

A. Definisi Penilaian Kinerja ................................................... 5

B. Penilaian Kinerja Pesawat ....................................................... 6

C. Tujuan dan Manfaat Penilaian Kinerja ............................... 7

D. Perfomace Standard( Standar Penilaian Kerja) .................. 8

E. Prinsip Penilaian Kinerja .................................................... 25

F. Proses Penilaian Kinerja .......................................................... 26

G. Metode Penilaian Kinerja ...................................................... 28

H. Outcomes Evaluasi Kinerja ............................................... 30

I. Hambatan dan Peilaian Kinerja .......................................... 32

BAB IV TEORI CARING

A. Teori Caring Kristen M. Swanson ...................................... 34

B. Dimensi Caring Menurut Kristen Swanson ......................... 37

C. Perilaku Caring dalam Praktik Keperawatan...................... 41

BAB V STANDARISASI SISTEM PENILAIAN KINERJA PERAWAT BERBASIS CARING

A. Pedoman Penyusunan SOP (Standar Operasional Prosedur) dan Alur (Flowchart) ......................................... 43

B. Pengertian SOP ............................................................... 43

C. Format SOP ........................................................................ 44

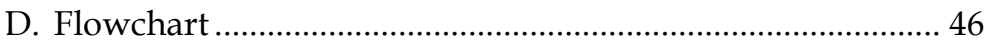

E. Langkah Peyusunan SOP ................................................. 46

F. Instrumen penilaian kinerja perawat pelaksana berbasis caring ...................................................................... 47

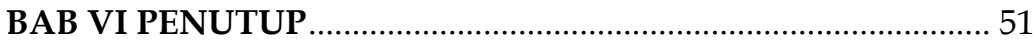

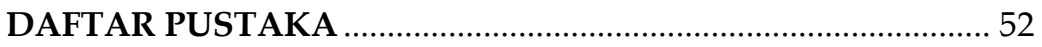




\section{BAB I PENDAHULUAN}

Rumah sakit sebagai salah satu fasilitas pelayanan kesehatan memiliki peran sangat strategis dalam upaya mempercepat peningkatan derajat kesehatan masyarakat Indonesia (Depkes RI, 2009). UU No 44 Tahun 2009 tentang rumah sakit menyebutkan bahwa rumah sakit harus tetap mampu meningkatkan pelayanan bermutu dan terjangkau oleh masyarakat. Peningkatan kualitas pelayanan rumah sakit harus disertai dengan peningkatan pelayanan keperawatan, salah satunya melalui upaya peningkatan kinerja perawat (Manuho, Warouw, \& Hamel, 2015). Penilaian kinerja merupakan faktor penting untuk kesuksesan manajemen kinerja (Mondy, 2008). Penilaian kinerja perawat merupakan salah satu upaya manajemen rumah sakit untuk memperbaiki dan meningkatkan kualitas pelayanan keperawatan (Ginting \& Setiawan, 2012; Hayati, 2014). Penilaian kinerja perawat dalam pelayanan keperawatan berdasarkan tingkat caring perawat sangat penting dan memiliki peran vital dalam kesuksesan sebuah rumah sakit. Penilaian kinerja yang tepat juga dapat meningkatkan motivasi perawat untuk memberikan pelayanan yang lebih baik kepada klien (Nikpeyma, Abed, Azargashb, \& Alavi, 2014). Masalah yang muncul dalam dalam proses penilaian kinerja perawat adalah kurangnya unsur caring selama proses penilaian kinerja (Carson, 2004). Alat penilaian kinerja perawat berdasarkan caring yang bertujuan untuk mengukur aktivitas caring perawat dirancang untuk merefleksikan persepsi staf perawat atas manajer mereka (Watson, 2002 dalam Hayati, 2014) sehingga meningkatkan kepuasan kinerja perawat yang memberikan peningkatan mutu asuhan keperawatan kepada klien. 


\section{BAB II \\ KINERJA}

\section{A. Pengertian Kinerja}

Kinerja merupakan gambaran mengenai tingkat pencapaian pelaksanaan suatu program kegiatan atau kebijakan dalam mewujudkan sasaran, visi, dan misi organisasi melalui perencanaan strategis organisasi (Moeheriono, 2009:60). Kinerja karyawan mempengaruhi seberapa banyak karyawan memberi konstribusi kepada organisasi, antara lain : kuantitas output, kualitas output, jangka waktu output, kehadiran di tempat kerja dan sikap kooperatif (Mathis, R \& Jackson, 2002:78). Kinerja sumber daya manusia adalah prestasi kerja atau hasil kerja (output) baik kualitas maupun kuantitas yang dicapai sumber daya manusia persatuan periode waktu dalam melaksanakan tugas kerja sesuai dengan tanggung jawab yang diberikan (Mangkunegara, 2005). Robbins (2008) dalam Moeheriono (2009: 61) menyebutkan bahwa kinerja sebagai fungsi interaksi antara kemampuan atau ability (A), motivasi atau motivation (M), dan kesempatan atau opportunity $(\mathrm{O})$, atau jika dirumuskan menjadi $\mathrm{P}=\mathrm{f}(\mathrm{MxAxO})$.

Deskripsi dari kinerja terdiri dari 3 komponen penting, yaitu : tujuan, ukuran, dan penilaian kinerja. Penentuan tujuan dari setiap unit organisasi merupakan strategi untuk meningkatkan kinerja. Tujuan akan memberikan arah dan mempengaruhi perilaku kerja yang diharapkan organisasi terhadap setiap karyawan. Penentuan tujuan belum cukup, karena dibutuhkan ukuran pencapaian kierja karyawan. Ukuran kuantitatif dan kualitatif standar kinerja untuk setiap tugas dan jabatan karyawan juga berperan penting. Komponen ketiga adalah penilaian kinerja. Penilaian kinerja secara reguler membuat karyawan senantiasa berorientasi terhadap tujuan dan berperilaku kerja sesuai dengan tujuan yang akan dicapai (Ilyas, 2002). Kinerja dapat diketahui dan diukur jika individu atau sekelompok karyawan telah 
mempunyai kriteria atau standar keberhasilan tolok ukur yang ditetapkan dalam pengukuran (Moeheriono, 2009:60). Dapat disimpulkan bahwa kinerja merupakan hasil yang dicapai atau prestasi kerja seseorang atau kelompok dalam menampilkan kemampuan sesuai dengan bidang tugas yang menjadi tanggung jawab untuk mewujudkan sasaran, visi, dan misi organisasi.

\section{B. Teori Kinerja}

Gibson et al. (2012) menyatakan bahwa tampilan kerja (job performance) adalah hasil akhir dari pekerjaan yang berhubungan dengan tujuan suatu organisasi berupa kualitas/ mutu, efisiensi, dan efektifitas. Gibson et al. (2005) menyampaikan model teori kinerja dan melakukan analisis terhadap sejumlah variabel yang mempengaruhi perilaku dan kinerja individu. Variabel individu dikelompokkan pada sub variabel kemampuan dan keterampilan, latar belakang dan demografis. Sub variabel kemampuan dan keterampilan merupakan faktor utama yang mempengaruhi perilaku dan kinerja individu. Variabel demografis mempunyai efek tidak langsung pada perilaku dan kinerja individu.

Variabel psikologis terdiri dari sub variabel persepsi, sikap, kepribadian, belajar, dan motivasi. Variabel organisasi digolongkan dalam sub variabel sumber daya, kepemimpinan, imbalan, stuktur dan job design. 


\begin{tabular}{|c|c|c|}
\hline $\begin{array}{l}\text { Variabel Individu : } \\
\text { 1) Kemampuan } \\
\text { dan } \\
\text { keterampilan : } \\
\text { a. Mental } \\
\text { b. Fisik } \\
\text { 2) Latar belakang: } \\
\text { a. Keluarga } \\
\text { b. Tingkst sosial } \\
\text { c. Pengalaman } \\
\text { 3) Demografis : } \\
\text { a. Umur } \\
\text { b. Etnis } \\
\text { c. Jenis Kelamin }\end{array}$ & $\begin{array}{l}\text { Variabel Organisasi : } \\
\text { 1) Sumber daya } \\
\text { 2) Kepemimpinan } \\
\text { 3) Imbalan } \\
\text { 4) Struktur } \\
\text { 5) Desain pekerjaan }\end{array}$ & $\begin{array}{l}\text { Variabel } \\
\text { Psikologis : } \\
\text { 1) Persepsi } \\
\text { 2) Sikap } \\
\text { 3) Kepribadian } \\
\text { 4) Belajar } \\
\text { 5) Motivasi }\end{array}$ \\
\hline
\end{tabular}




\section{BAB III \\ PENILAIAN KINERJA}

\section{A. Definisi Penilaian Kinerja}

Penilaian kinerja merupakan kegiatan untuk menilai keberhasilan atau kegagalan seorang pegawai dalam melaksanakan tugasnya. Penilaian kinerja harus berpedoman pada ukuran yang telah disepakati bersama dalam standar kerja (Husaini, 2011). Penilaian kinerja adalah suatu proses yang diawali dengan penetapan standar kinerja yang membutuhkan umpan balik dari pegawai, mengontrol sumber daya manusia dan produktifitasnya, suatu ukuran pengawasan, alat yang menyelidiki kinerja dan kepuasan kerja yang dapat diukur dengan menggunakan tehnik komunikasi yang efektif yang bertujuan untuk mengetahui apakah pegawai mampu atau tidak mencapai kinerja yang telah ditetapkan sesuai dengan visi, dan misi dari suatu organisasi (Hayati, 2014). Pengukuran kinerja (performance measurement) mempunyai pengertian suatu proses penilaian tentang kemajuan pekerjaan terhadap tujuan dan sasaran dalam pengelolaan sumber daya manusia untuk menghasilkan barang dan jasa, termasuk informasi atas efisiensi serta efektivitas tindakan dalam mencapai tujuan organisasi (Moeheriono, 2009:61). Penilaian kinerja perawat dilakukan untuk menjamin tercapainya standar praktek keperawatan dan ketentuan lain yang terkait (PPNI, 2005).

Aspek yang mendasar dan paling pokok dari pengukuran kinerja menurut Moeheriono (2009:61), yaitu sebagai berikut:

1. Menetapkan tujuan, sasaran dan strategi organisasi, dengan menetapkan secara umum apa yang diinginkan oleh organisasi sesuai dengan tujuan, visi dan misinya.

2. Merumuskan indikator kinerja dan ukuran kinerja, yang mengacu pada penilaian kunerja secara tidak langsung, 
sedangkan indikator kinerja mengacu pada pengukuran kinerja secara langsung yang berbentuk keberhasilan utama (critical success factors) dan indikator kinerja kunci (key performance indicator).

3. Mengukur tingkat capaian tujuan dan sasaran organisasi, menganalisis hasil pengukuran kinerja yang dapat diimplementasikan dengan membandingkan tingkat capaian tujuan dan sasaran organisasi.

4. Mengevaluasi kinerja dengan menilai kemajuan organisasi dan pengambilan keputusan yang berkualitas, memberikan gambaran atau hasil kepada organisasi seberapa besar tingkat keberhasilan tersebut dan mengevaluasi langkah apa yang diambil organisasi selanjutnya.

Berdasarkan pendapat dari beberapa ahli tentang pengertian penilaian kinerja dapat ditarik kesimpulan bahwa penilaian kinerja perawat adalah suatu sistem penilaian terhadap kinerja perawat berdasarkan visi dan misi rumah sakit yang dilakukan secara berkala untuk menjamin tercapainya standar praktek profesional keperawatan.

\section{B. Penilaian Kinerja Perawat}

Penilaian kinerja perawat mencerminkan secara langsung rencana strategik Rumah Sakit yang hasilnya diperlukan untuk mengembangkan kebijakan tentang keperawatan berbasis kinerja sehingga dapat meningkatkan kinerja perawat di RS (Hafizurrachman, Trisnantoro, \& Bachtiars, 2012). Penilaian kinerja perawat termasuk standar ketiga kinerja profesional perawat (PPNI, 2005) bertujuan untuk menjamin tercapainya pemberian asuhan keperawatan di Indonesia. Pemberian asuhan keperawatan meliputi pengkajian, diagnosa keperawatan, intervensi, implementasi, dan evaluasi (PPNI, 2005). Standar penilaian kinerja profesional (Muhith, 2013; Nursalam, 2015) terdiri dari 6 unsur, yaitu caring, kolaborasi, empathy, kecepatan respons, courtesey, dan sincerity. Pengembangan dan penggunaan alat penilaian kinerja perawat pelaksana berbasis caring direkomendasikan untuk 
menjamin mutu pemberian asuhan keperawatan terhadap klien.

Peningkatan mutu pelayanan keperawatan didukung oleh pengembangan teori keperawatan, salah satunya adalah model caring yang dikembangkan oleh Kristen M. Swanson (1993). Teori caring Swanson menjelaskan tentang proses caring yang terdiri dari bagaimana perawat mengerti kejadian yang berarti di dalam hidup seseorang (maintenence belief dan knowing), hadir secara emosional (being with), melakukan suatu hal kepada orang lain sama seperti melakukan terhadap diri sendiri (doing for), memberi informasi dan memudahkan jalan seseorang dalam menjalani transisi kehidupan serta menaruh kepercayaan seseorang dalam menjalani hidupnya (enabling). Hasil akhir dari teori caring Swanson adalah untuk meningkatkan kesejahteran klien (well-being). Perilaku caring harus ditanamkan dan menjadi budaya yang melekat pada perawat dalam pemberian asuhan keperawatan sehingga setiap tindakan atau asuhan yang diberikan sebagai bentuk pemuasan kebutuhan klien.

Penilaian kinerja perawat sebagai hasil dari pencapaian kualitas pemberian asuhan keperawatan terhadap klien dalam aplikasinya dibutuhkan pengembangan yang merujuk Teori Caring Swanson..

\section{Tujuan dan Manfaat Penilaian Kinerja}

Tujuan dari penilaian kinerja adalah untuk melengkapi rencana tindakan dalam waktu yang telah ditetapkan. Fokus terhadap suatu rencana tindakan merupakan suatu yang penting dimana perawat dapat mengenal kelemahan dan kekuatan untuk kesiapan karir mereka dimasa depan (Swansburg, 2000).

Penilaian kinerja menurut Werther dan Davis (1996:342) mempunyai beberapa tujuan dan manfaat bagi organisasi dan pegawai yang dinilai, yaitu:

1. Performance Improvement. Yaitu memungkinkan pegawai dan manajer untuk mengambil tindakan yang berhubungan 
dengan peningkatan kinerja.

2. Compensation adjustment. Membantu para pengambil keputusan untuk menentukan siapa saja yang berhak menerima kenaikan gaji atau sebaliknya.

3. Placement decision. Menentukan promosi, transfer, dan demotion.

4. Training and development needs mengevaluasi kebutuhan pelatihan dan pengembangan bagi pegawai agar kinerja mereka lebih optimal.

5. Carrer planning and development. Memandu untuk menentukan jenis karir dan potensi karir yang dapat dicapai.

6. Staffing process deficiencies. Mempengaruhi prosedur perekrutan pegawai.

7. Informational inaccuracies and job-design errors. Membantu menjelaskan apa saja kesalahan yang telah terjadi dalam manajemen sumber daya manusia terutama di bidang informasi job-analysis, job-design, dan sistem informasi manajemen sumber daya manusia.

8. Equal employment opportunity. Menunjukkan bahwa placement decision tidak diskriminatif.

9. External challenges. Kadang-kadang kinerja pegawai dipengaruhi oleh faktor eksternal seperti keluarga, keuangan pribadi, kesehatan, dan lain- lainnya. Biasanya faktor ini tidak terlalu kelihatan, namun dengan melakukan penilaian kinerja, faktor eksternal ini akan kelihatan sehingga membantu departemen sumber daya manusia untuk memberikan bantuan bagi peningkatan kinerja pegawai.

10. Feedback. Memberikan umpan balik bagi urusan kepegawaian maupun bagi pegawai itu sendiri.

\section{Performance Standard (Standar Penilaian Kinerja)}

Penilaian kinerja sangat membutuhkan standar yang jelas yang dijadikan tolok ukur atau patokan terhadap kinerja yang akan diukur. Menurut Werther dan Davis (1996:344), 
standar yang dibuat tentu saja harus berhubungan dengan jenis pekerjaan yang akan diukur dan hasil yang diharapkan akan terlihat dengan adanya penilaian kinerja ini. Ada empat hal yang harus diperhatikan dalam menyusun standar penilaian kinerja yang baik dan benar yaitu validity, agreement, realism, dan objectivity.

1. Validity adalah keabsahan standar tersebut sesuai dengan jenis pekerjaan yang dinilai. Keabsahan yang dimaksud di sini adalah standar tersebut memang sesuai atau relevan dengan jenis pekerjaan yang akan dinilai tersebut.

2. Agreement berarti persetujuan, yaitu standar penilaian tersebut disetujui dan diterima oleh semua pegawai yang akan mendapat penilaian. Ini berkaitan dengan prinsip validity di atas.

3. Realism berarti standar penilaian tersebut bersifat realistis, dapat dicapai oleh para pegawai dan sesuai dengan kemampuan pegawai.

4. Objectivity berarti standar tersebut bersifat obyektif, yaitu adil, mampu mencerminkan keadaan yang sebenarnya tanpa menambah atau mengurangi kenyataan dan sulit untuk dipengaruhi oleh bias penilai.

Kriteria penilaian kinerja dapat dilihat melalui beberapa dimensi, yaitu kegunaan fungsional (functional utility), keabsahan (validity), empiris (empirical base), sensitivitas (sensitivity), pengembangan sistematis (systematic development), dan kelayakan hukum (legal appropriateness).

Kegunaan fungsional bersifat krusial, karena hasil penilaian kinerja dapat digunakan untuk melakukan seleksi, kompensasi, dan pengembangan pegawai, maka hasil penilaian kinerja harus valid, adil, dan berguna sehingga dapat diterima oleh pengambil keputusan.

1. Valid atau mengukur apa yang sebenarnya hendak diukur dari penilaian kinerja tersebut.

2. Bersifat empiris, bukan berdasarkan perasaan semata 
3. Sensitivitas kriteria. Kriteria itu menunjukkan hasil yang relevan saja, yaitu kinerja, bukan hal-hal lainnya yang tidak berhubungan dengan kinerja.

4. Sistematika kriteria. Hal ini tergantung dari kebutuhan organisasi dan lingkungan organisasi. Kriteria yang sistematis tidak selalu baik.

5. Organisasi yang berada pada lingkungan yang cepat berubah mungkin justru lebih baik menggunakan kriteria yang kurang sistematis untuk cepat menyesuaikan diri dan begitu juga sebaliknya.

6. Kelayakan hukum yaitu kriteria itu harus sesuai dengan hukum yang berlaku.

Pengembangan dan penggunaan standar penilaian kinerja perawat diantaranya mengacu pada :

Peraturan Pemerintah No 46 TAHUN 2011 tentang

Penilaian Prestasi Kerja Pegawai Negeri Sipil

\section{BAB I KETENTUAN UMUM}

Pasal 1

a. Penilaian prestasi kerja PNS adalah suatu proses penilaian secara sistematis yang dilakukan oleh pejabat penilai terhadap sasaran kerja pegawai dan perilaku kerja PNS.

b. Prestasi kerja adalah hasil kerja yang dicapai oleh setiap PNS pada satuan organisasi sesuai dengan sasaran kerja pegawai dan perilaku kerja.

c. Sasaran Kerja Pegawai yang selanjutnya disingkat SKP adalah rencana kerja dan target yang akan dicapai oleh seorang PNS.

d. Target adalah jumlahbeban kerja yang akan dicapai dari setiap pelaksanaan tugas jabatan.

e. Perilaku kerja adalah setiap tingkah laku, sikap atau tindakan yang dilakukan oleh PNS atau tidak 
melakukan sesuatu yang seharusnya dilakukan sesuai dengan ketentuan peraturan perundang-undangan.

\section{Pasal 4}

Penilaian prestasi kerja PNS terdiri atas unsur: SKP dan Perilaku kerja.

\section{Pasal 8}

f. Penilaian SKP sebagaimana dimaksud dalam Pasal 4 huruf a dilakukan dengan cara membandingkan antara realisasi kerja dengan target.

g. Dalam hal realisasi kerja melebihi dari target maka penilaian SKP sebagaimana dimaksud pada ayat (1) capaiannya dapat lebih dari 100 (seratus).

Pasal 9

Dalam hal SKP tidak tercapai yang diakibatkan oleh faktor diluar kemampuan individu PNS maka penilaian didasarkan pada pertimbangan kondisi penyebabnya.

\section{BAB III PERILAKU KERJA}

Pasal 12

1. Penilaian perilaku kerja sebagaimana dimaksud dalam Pasal 4 huruf b meliputi aspek : Orientasi pelayanan; Integritas; Kornitrnen; Disiplin; Kerja sarna; dan Kepernirnpinan.

2. Penilaian kepemimpinan sebagairnana dirnaksud pada ayat (1) huruf f hanya dilakukan bagi PNS yang rnenduduki jabatan struktural.

\section{Pasal 13}

1. Penilaian perilaku kerja sebagairnana dirnaksud dalam Pasal 12 dilakukanmelalui pengamatan oleh pejabat penilai terhadap PNS sesuai kriteria yang ditentukan.

2. Pejabat penilai dalam melakukan penilaian perilaku kerja PNS sebagaimana dimaksud pada ayat (1) dapat mernpertimbangkan masukan dari pejabat penilai lain yang setingkat di lingkungan unit kerja masing-masing.

3. Nilai perilaku kerja dapat diberikan paling tinggi 100 
(seratus).

\author{
BAB IV PENILAIAN
}

Bagian Kesatu Tata Cara Penilaian

\title{
Pasal 15
}

1. Penilaian prestasi kerja sebagaimana dimaksud dalam Pasal 4 dilakukan dengan cara menggabungkan penilaian SKP dengan penilaian perilaku kerja.

2. Bobot nilai unsur SKP $60 \%$ (enam puluh persen) dan perilaku kerja $40 \%$ (empat puluh persen).

\section{Pasal 16}

1. Penilaian prestasi kerja PNS sebagaimana dimaksud dalam Pasal 4 dilaksanakan oleh pejabat penilai sekali dalam 1 (satu) tahun.

2. Penilaian prestasi kerja sebagaimana dimaksud pada ayat (1) dilakukan setiap akhir Desember pada tahun yang bersangkutan dan paling lama akhir Januari tahun berikutnya.

\section{Pasal 17}

Nilai prestasi kerja PNS sebagaimana dimaksud dalam Pasal 15 dinyatakan dengan angka dan sebutan sebagai berikut:

91 - ke atas: sangat baik

76 - 90: baik

61 -75: cukup

51 - 60: kurang

50 ke bawah: buruk

\section{UU Keperawatan No. 38 Tahun 2014 Bab V tentang Praktik Keperawatan \\ Pasal 28}

1. Praktik Keperawatan dilaksanakan di Fasilitas Pelayanan Kesehatan dan tempat lainnya sesuai dengan Klien sasarannya.

2. Praktik Keperawatan sebagaimana dimaksud pada ayat (1) terdiri atas: Praktik Keperawatan mandiri; dan Praktik 
Keperawatan di Fasilitas Pelayanan Kesehatan.

3. Praktik Keperawatan sebagaimana dimaksud pada ayat (1) harus didasarkan pada kode etik, standar pelayanan, standar profesi, dan standar prosedur operasional.

4. Praktik Keperawatan sebagaimana dimaksud pada ayat (2) didasarkan pada prinsip kebutuhan pelayanan kesehatan dan/atau Keperawatan masyarakat dalam suatu wilayah.

5. Ketentuan lebih lanjut mengenai kebutuhan pelayanan kesehatan dan/atau Keperawatan dalam suatu wilayah sebagaimana dimaksud pada ayat (4) diatur dengan Peraturan Menteri.

\section{Pasal 29}

1. Dalam menyelenggarakan Praktik Keperawatan, Perawat bertugas sebagai: pemberi Asuhan Keperawatan; penyuluh dan konselor bagi Klien; pengelola Pelayanan Keperawatan; peneliti Keperawatan; pelaksana tugas berdasarkan pelimpahan wewenang; dan/atau pelaksana tugas dalam keadaan keterbatasan tertentu.

2. Tugas sebagaimana dimaksud pada ayat (1) dapat dilaksanakan secara bersama ataupun sendiri-sendiri.

3. Pelaksanaan tugas Perawat sebagaimana dimaksud pada ayat (1) harus dilaksanakan secara bertanggung jawab dan akuntabel.

\section{Pasal 30}

1. Dalam menjalankan tugas sebagai pemberi Asuhan Keperawatan di bidang upaya kesehatan perorangan, Perawat berwenang: melakukan pengkajian Keperawatan secara holistik; menetapkan diagnosis Keperawatan; merencanakan tindakan Keperawatan; melaksanakan tindakan Keperawatan; mengevaluasi hasil tindakan Keperawatan; melakukan rujukan; memberikan tindakan pada keadaan gawat darurat sesuai dengan kompetensi; memberikan konsultasi Keperawatan dan berkolaborasi dengan dokter; melakukan penyuluhan kesehatan dan konseling; dan melakukan penatalaksanaan pemberian obat 
kepada Klien sesuai dengan resep tenaga medis atau obat bebas dan obat bebas terbatas.

2. Dalam menjalankan tugas sebagai pemberi Asuhan Keperawatan di bidang upaya kesehatan masyarakat, Perawat berwenang: melakukan pengkajian Keperawatan kesehatan masyarakat di tingkat keluarga dan kelompok masyarakat; menetapkan permasalahan Keperawatan kesehatan masyarakat; membantu penemuan kasus penyakit; merencanakan tindakan Keperawatan kesehatan masyarakat; melaksanakan tindakan Keperawatan kesehatan masyarakat; melakukan rujukan kasus; mengevaluasi hasil tindakan Keperawatan kesehatan masyarakat; melakukan pemberdayaan masyarakat; melaksanakan advokasi dalam perawatan kesehatan masyarakat; menjalin kemitraan dalam perawatan kesehatan masyarakat; melakukan penyuluhan kesehatan dan konseling; mengelola kasus; dan melakukan penatalaksanaan Keperawatan komplementer dan alternatif.

\section{Pasal 31}

1. Dalam menjalankan tugas sebagai penyuluh dan konselor bagi Klien, Perawat berwenang:melakukan pengkajian Keperawatan secara holistik di tingkat individu dan keluarga serta di tingkat kelompok masyarakat; melakukan pemberdayaan masyarakat; melaksanakan advokasi dalam perawatan kesehatan masyarakat; menjalin kemitraan dalam perawatan kesehatan masyarakat;dan melakukan penyuluhan kesehatan dan konseling.

2. Dalam menjalankan tugasnya sebagai pengelola Pelayanan Keperawatan, Perawat berwenang: melakukan pengkajian dan menetapkan permasalahan; merencanakan, melaksanakan, dan mengevaluasi Pelayanan Keperawatan; dan mengelola kasus.

3. Dalam menjalankan tugasnya sebagai peneliti Keperawatan, Perawat berwenang: melakukan penelitian sesuai dengan standar dan etika; menggunakan sumber daya pada Fasilitas Pelayanan Kesehatan atas izin pimpinan; dan menggunakan 
pasien sebagai subjek penelitian sesuai dengan etika profesi dan ketentuan peraturan perundang-undangan.

\section{Pasal 32}

1. Pelaksanaan tugas berdasarkan pelimpahan wewenang sebagaimana dimaksud dalam Pasal 29 ayat (1) huruf e hanya dapat diberikan secara tertulis oleh tenaga medis kepada Perawat untuk melakukan sesuatu tindakan medis dan melakukan evaluasi pelaksanaannya.

2. Pelimpahan wewenang sebagaimana dimaksud pada ayat (1) dapat dilakukan secara delegatif atau mandat.

3. Pelimpahan wewenang secara delegatif untuk melakukan sesuatu tindakan medis diberikan oleh tenaga medis kepada Perawat dengan disertai pelimpahan tanggung jawab.

4. Pelimpahan wewenang secara delegatif sebagaimana dimaksud pada ayat (3) hanya dapat diberikan kepada Perawat profesi atau Perawat vokasi terlatih yang memiliki kompetensi yang diperlukan.

5. Pelimpahan wewenang secara mandat diberikan oleh tenaga medis kepada Perawat untuk melakukan sesuatu tindakan medis di bawah pengawasan.

6. Tanggung jawab atas tindakan medis pada pelimpahan wewenang mandat sebagaimana dimaksud pada ayat (5) berada pada pemberi pelimpahan wewenang.

7. Dalam melaksanakan tugas berdasarkan pelimpahan wewenang sebagaimana dimaksud pada ayat (1), Perawat berwenang: melakukan tindakan medis yang sesuai dengan kompetensinya atas pelimpahan wewenang delegatif tenaga medis; melakukan tindakan medis di bawah pengawasan atas pelimpahan wewenang mandat; dan memberikan pelayanan kesehatan sesuai dengan program Pemerintah.

\section{Pasal 33}

1. Pelaksanaan tugas dalam keadaan keterbatasan tertentu sebagaimana dimaksud dalam Pasal 29 ayat (1) huruf f merupakan penugasan Pemerintah yang dilaksanakan pada keadaan tidak adanya tenaga medis dan/atau tenaga 
kefarmasian di suatu wilayah tempat Perawat bertugas.

2. Keadaan tidak adanya tenaga medis dan/atau tenaga kefarmasian di suatu wilayah tempat Perawat bertugas sebagaimana dimaksud pada ayat (1) ditetapkan oleh kepala Satuan Kerja Perangkat Daerah yang menyelenggarakan urusan pemerintahan di bidang kesehatan setempat.

3. Pelaksanaan tugas pada keadaan keterbatasan tertentu sebagaimana dimaksud pada ayat (1) dilaksanakan dengan memperhatikan kompetensi Perawat.

4. Dalam melaksanakan tugas pada keadaan keterbatasan tertentu sebagaimana dimaksud pada ayat (1), Perawat berwenang: melakukan pengobatan untuk penyakit umum dalam hal tidak terdapat tenaga medis; merujuk pasien sesuai dengan ketentuan pada sistem rujukan; dan melakukan pelayanan kefarmasian secara terbatas dalam hal tidak terdapat tenaga kefarmasian.

\section{Pasal 34}

Ketentuan lebih lanjut mengenai tugas dan wewenang Perawat diatur dengan Peraturan Menteri.

\section{Pasal 35}

1. Dalam keadaan darurat untuk memberikan pertolongan pertama, Perawat dapat melakukan tindakan medis dan pemberian obat sesuai dengan kompetensinya.

2. Pertolongan pertama sebagaimana dimaksud pada ayat (1) bertujuan untuk menyelamatkan nyawa Klien dan mencegah kecacatan lebih lanjut.

3. Keadaan darurat sebagaimana dimaksud pada ayat (1) merupakan keadaan yang mengancam nyawa atau kecacatan Klien.

4. Keadaan darurat sebagaimana dimaksud pada ayat (1) ditetapkan oleh Perawat sesuai dengan hasil evaluasi berdasarkan keilmuannya.

5. Ketentuan lebih lanjut mengenai keadaan darurat sebagaimana dimaksud pada ayat (1) diatur dengan Peraturan Menteri. 


\section{Permenpan No. 25 Tahun 2014 tentang Jabatan Fungsional}

Perawat dan Angka Kredit

\section{BAB II}

\section{RUMPUN JABATAN, KEDUDUKAN, DAN TUGAS POKOK}

Pasal 2

Jabatan Fungsional Perawat termasuk dalam rumpun kesehatan.

\section{Pasal 3}

1. Perawat berkedudukan sebagai pelaksana teknis fungsional di bidang pelayanan keperawatan pada Fasilitas Pelayanan Kesehatan atau Fasilitas Pelayanan Kesehatan Lainnya di lingkungan instansi pemerintah.

2. Perawat sebagaimana dimaksud pada ayat (1) merupakan jabatan karier.

\section{Pasal 4}

Tugas pokok Perawat adalah melakukan kegiatan pelayanan keperawatan yang meliputi asuhan keperawatan, pengelolaan keperawatan dan pengabdian pada masyarakat.

\section{Kode Etik Keperawatan}

Kode etik keperawatan di Indonesia telah disusun oleh Dewan Pimpinan Pusat Persatuan Perawat Nasional Indonesia melalui Musyawarah Nasional PPNI VIII di Balikpapan pada tahun 2010.

\section{Perawat dan Klien}

a. Perawat dalam memberikan pelayanan keperawatan menghargai harkat dan martabat manusia, keunikan klien dan tidak terpengaruh oleh pertimbangan kebangsaan, kesukuan, warna kulit, jenis kelamin, aliran politik dan agama yang dianut serta kedudukan sosial.

b. Perawat dalam memberikan pelayanan keperawatan senantiasa memelihara suasana lingkungan yang menghormati nilai - nilai budaya, adat istiadat dan kelangsungan beragama dan klien.

c. Tanggung jawab adalah kepada mereka yang membutuhkan asuhan keperawatan.

d. Perawatan wajib merahasiakan segala sesuatu yang 
diketahui sehubungan dengan tugas yang dipercayakan kepadanya kecuali jika diperlukan oleh yang berwenang sesuai dengan ketentuan hukum yang berlaku

\section{Perawat dan Praktek}

a. Perawat memelihara dan meningkatkan kompetisi dibidang keperawatan melalui belajar terus menerus.

b. Perawat senantiasa memelihara mutu pelayanan keperawatan yang tinggi disertai kejujuran profesional yang menerapkan pengetahuan serta ketrampilan keperawatan sesuai dengan kebutuhan klien.

c. Perawat dalam membuat keputuasan didasarkan pada informasi yang akurat dan mempertimbangkan kemampuan serta kualifikasi seseorang bila melakukan konsultasi, menerima delegasi dan memberikan delegasi kepada orang lain.

d. Perawat senantiasa menjunjung tinggi nama baik profesi keperawatan dengan selalu menunjukkan perilaku profesional.

\section{Perawat dan Masyarakat}

Perawat mengemban tanggungjawab bersama masyarakat untuk memprakarsai dan mendukung berbagai kegiatan dalam memenuhi kebutuhan dan kesehatan masyarakat.

\section{Perawat dan Teman Sejawat}

a. Perawat senantiasa memelihara hubungan baik dengan sesama perawat maupun dengan tenaga kesehatan lainnya, dan dalam memelihara keserasian suasana lingkungan kerja maupun dalam mencapai tujuan pelayanan kesehatan secara menyeluruh

b. Perawat bertindak melindungi klien dari tenaga kesehatan yang memberikan pelayanan kesehatan secara tidak kompeten, tidak etis dan ilegal.

\section{Perawat dan Profesi}

a. Perawat mempunyai peran utama dalam menentukan standar pendidikan dan pelayanan keperawatan serta menerapkan dalam kegiatan pelayanan dan pendidikan keperawatan. 
b. Perawat berperan aktif dalam kegiatan pengembangan profesi keperawatan.

c. Perawat berpartisipasi aktif dalam upaya profesi untuk membangun dan memelihara kondisi kerja yang kondusif demi terwujudnya asuhan keperawatan yang bermutu tinggi

\section{Standar Kinerja Profesional}

Standar kinerja profesional perawat (Muhith, 2013;

Nursalam, 2015) terdiri dari enam unsur, yaitu :

a. Caring, yaitu sikap tanggap perawat terhadap kebutuhan klien dan keberadaan perawat untuk memberikan pelayanan kepada klien.

b. Kolaborasi, yaitu kerjasama antara perawat dengan teman sejawat, tim kesehatan, klien dan keluarga klien dalam menyelesaikan masalah klien.

c. Empathy, yaitu pemberian pelayanan secara individual dengan penuh perhatian dan sesuai kebutuhan/ harapan klien. Perawat mau mendengar keluhan, memperhatikan dan membantu klien dalam menyelesaikan masalah.

d. Kecepatan respons, yaitu keinginan membantu dan menyediakan pelayanan yang dibutuhkan klien dengan segera. Indikator responsiveness adalah kecepatan pelayanan, dan waktu tunggu yang pendek dalam pelayanan.

e. Courtesy, yaitu perilaku perawat yang sopan dengan menghargai klien, tenaga kesehatan lain, dan sesama perawat.

f. Sincerity, yaitu kondisi kualitas perawat yang didasarkan pada kejujuran antara pikiran dan tindakan.

\section{Standar Praktek Profesional Perawat}

Penilaian kualitas pelayanan keperawatan kepada klien menggunakan standar praktik profesional perawat yang merupakan pedoman bagi perawat dalam melaksanakan asuhan keparawatan. Di Indonesia standar praktik keperawatan mengacu pada standar praktik profesional 
Persatuan Perawat Nasional Indonesia (PPNI) tahun 2005.

Standar praktik profesional mengacu dalam tahapan proses keperawatan, meliputi: (1) pengkajian, (2) diagnosa keperawatan, (3) perencanaan, (4) implementasi, dan (5) evaluasi.

1. Standar I : Pengkajian Keperawatan

Perawat mengumpulkan data tentang status kesehatan klien secara sistematis, menyeluruh, akurat, singkat dan berkesinambungan.

Rasional : Pengkajian keperawatan merupakan aspek penting dalam proses keperawatan yang bertujuan menetapkan data dasar tentang tingkat kesehatan klien yang digunakan untuk merumuskan masalah klien dan rencana tindakan.

Kriteria Struktur :

Metode pengumpulan data yang digunakan dapat menjamin :

a. Pengumpulan data yang sistematis dan lengkap.

b. Diperbaharuinya data dalam pencatatan yang ada.

c. Kemudahan memperoleh data.

d. Terjaganya kerahasiaan.

e. Tatanan praktek mempunyai sistem pengumpulan data keperawatan yang merupakan bagian integral dari sistem pencatatan pengumpulan data klien

f. Sistem pencatatan berdasarkan proses keperawatan. Singkat, menyeluruh, akurat dan berkesinambungan.

g. Praktek mempunyai sistem pengumpulan data keperawatan yang menjadi bagian dari sistem pencatatan kesehatan klien.

h. Ditatanan praktek tersedia sistem penyimpanan data yang dapat memungkinkan diperoleh kembali bila diperlukan.

i. Tersedianya sarana dan lingkungan yang mendukung. 
Kriteria Proses :

h. Pengumpulan data dilakukan dengan cara wawancara, observasi, pemeriksaan fisik dan mempelajari data penunjang (pengumpulan data penunjang diperoleh dari hasil pemeriksaan laboratorium dan uji diagnosis), serta mempelajari catatan lain.

i. Sumber data adalah klien, keluarga atau orang terkait, tim kesehatan, rekam medis, serta catatan lain.

j. Klien berpartisipasi dalam proses pengumpulan data.

k. Data yang dikumpulkan, difokuskan untuk mengidentifikasi :

a. Status kesehatan klien saat ini

b. Status kesehatan klien masa lalu

c. Status biologis (Fisiologis)

d. Status psikologis (Pola koping)

e. Status social cultural

f. Status spiritual

g. Respon terhadap terapi

h. Harapan terhadap tingkat kesehatan yang optimal

i. Resiko masalah potensial Kriteria Hasil :

Data dicatat dan dianalisis sesuai standar dan format yang ada.

Data yang dihasilkan akurat, terkini, dan relevan sesuai kebutuhan klien.

2. Standar II : Diagnosa Keperawatan.

Perawat menganalisa data pengkajian untuk merumuskan diagnosa keperawatan.

Rasional : Diagnosis keperawatan sebagai dasar pengembangan rencana intervensi keperawatan dalam rangka mencapai peningkatan, pencegahan dan penyembuhan penyakit serta pemulihan kesehatan klien.

Kriteria Struktur :

Tatanan praktek memberi kesempatan ; 
a. kepada teman sejawat, klien untuk melakukan validasi diagnosis keperawatan

b. adanya mekanisme pertukaran informasi tentang hasil penelitian dalam menetapkan diagnosis keperawatan yang tepat.

c. Untuk akses sumber-sumber dan program pengembangan profesional yang terkait.

d. adanya pencatatan yang sistematis tentang diagnosis klien. Kriteria Proses :

a. Proses diagnosa keperawatan terdiri dari : analisis, interpretasi data, identifikasi masalah klien dan perumusan diagnosis keperawatan.

b. Diagnosa keperawatan terdiri dari: masalah $(\mathrm{P})$, penyebab (E) dan tanda atau gejala (S), atau terdiri dari masalah dan penyebab (PE).

c. Bekerja sama dengan klien, dekat dengan klien, petugas kesehatan lain untuk memvalidasi diagnosis keperawatan.

d. Melakukan kajian ulang dan revisi diagnosis berdasarkan data terbaru.

Kriteria Hasil :

a. Diagnosis keperawatan divalidasi oleh klien bila memungkinkan

b. Diagnosis keperawatan yang dibuat diterima oleh teman sejawat sebagai diagnosis yang relevan dan signifikan.

c. Diagnosis didokumentasikan untuk memudahkanperencanaan, implementasi, evaluasi dan penelitian.

3. Standar III: Perencanaan Keperawatan

Perawat membuat rencana tindakan keperawatan untuk mengatasi masalah dan meningkatkan kesehatan klien.

Rasional : Perencanaan dikembangkan berdasarkan diagnosis keperawatan Kriteria Struktur :

Tatanan praktek menyediakan :

a. Sarana yang dibutuhkan untuk mengembangkan perencanaan.

b. Adanya mekanisme pencatatan, sehingga dapat dikomunikasikan Kriteria Proses : 
Perencanaan terdiri dari penetapan prioritas masalah, tujuan dan rencana tindakan keperawatan. Bekerjasama dengan klien dalam menyusun rencana tindakan keperawatan. Perencanaan bersifat individual (sebagai individu, kelompok dan masyarakat) sesuai dengan kondisi atau kebutuhan klien. Mendokumentasi rencana keperawatan.

Kriteria Hasil :

a. Tersusunnya suatu rencana asuhan keperawatan klien

b. Perencanaan mencerminkan penyelesaian terhadap diagnosis keperawatan.

c. Perencanaan tertulis dalam format yang singkat dan mudah didapat.

d. Perencanaan menunjukkan bukti adanya revisi pencapaian tujuan.

4. Standar IV : Pelaksanaan Tindakan (Implementasi)

Perawat mengimplementasikan tindakan yang telah diidentifikasi dalam rencana asuhan keperawatan.

Rasional : Perawat mengimplementasikan rencana asuhan keperawatan untuk mencapai tujuan yang telah ditetapkan dan partisipasi klien dalam tindakan keperawatan berpengaruh pada hasil yang diharapkan.

Kriteria Struktur :

Tatanan praktek menyediakan :

a. Sumber daya untuk pelaksanaan kegiatan.

b. Pola ketenagaan yang sesuai kebutuhan.

c. Ada mekanisme untuk mengkaji dan merevisi pola ketenagaan secara periodik.

d. Pembinaan dan peningkatan keterampilan klinis keperawatan.

e. Sistem Konsultasi keperawatan

Kriteria Proses :

Bekerjasama dengan klien dalam pelaksanaan tindakan keperawatan.

Kolaborasi dengan profesi kesehatan lain untuk meningkatkan status kesehatan klien 
Melakukan tindakan keperawatan untuk mengatasi kesehatan klien.

Memberikan supervisi terhadap tenaga pelaksana keperawatan dibawah tanggung jawabnya

Menjadi koordinator pelayanan dan advokasi terhadapklien untuk mencapai tujuan kesehatan

Menginformasikan kepada klien tentang status kesehatan dan fasilitas- fasilitas pelayanan kesehatan yang ada.

Memberikan pendidikan pada klien dan keluarga mengenai konsep, keterampilan asuhan diri serta membantu klien memodifikasi lingkunngan yang digunakan.

Mengkaji ulang dan merevisi pelaksanaan tindakan keperawatan berdasarkan respon klien.

Kriteria Hasil :

a. Terdokumentasi tindakan keperawatan dan respon klien secara sistematik dan dengan mudah diperoleh kembali.

b. Tindakan keperawatan dapat diterima klien.

c. Ada bukti-bukti yang terukur tentang pencapaian tujuan

5. Standar V: Evaluasi Keperawatan

Perawat mengevaluasi perkembangan klien terhadap tindakan dalam pencapaian tujuan, sesuai rencana yang telah ditetapkan dan merevisi data dasar dan perencanaan.

Rasional : Praktek keperawatan merupakan suatu proses dinamis yang mencakup berbagai perubahan data, diagnosa atau perencanaan yang telah

dibuat sebelumnya. Efektivitas asuhan keperawatan tergantung pada pengkajian yang berulang-ulang.

Kriteria Struktur :

a. Tatanan praktek menyediakan : sarana dan lingkungan yang mendukung terlaksananya proses evaluasi.

b. Adanya akses informasi yang dapat digunakan perawat dalam penyempurnaan perencanaan

c. Adanya supervisi dan konsultasi untuk membantu perawat melakukan evaluasi secara effektif dan mengembangkan alternatif perencanaan yang tepat.

Kriteria Proses : 
a. Menyusun perencanaan evaluasi hasil tindakan secara komprehensif, tepat waktu dan terus menerus.

b. Menggunakan data dasar dan respon klien dalam mengukur perkembangan kearah pencapaian tujuan.

c. Memvalidasi dan menganalisis data baru dengan teman sejawat dan klien.

d. Bekerjasama dengan klien, keluarga untuk memodifikasi rencana asuhan keperawatan.

e. Mendokumentasikan hasil evaluasi dan memodifikasi perencanaan

f. Melakukan supervisi dan konsultasi klinik Kriteria Hasil :

Diperolehnya hasil revisi data, diagnosis, rencana tindakan berdasarkan evaluasi.

Klien berpartisipasi dalam proses evaluasi dan revisi rencana tindakan.

Hasil evaluasi digunakan untuk mengambil keputusan

Evaluasi tindakan terdokumentasikan sedemikian rupa yang menunjukan kontribusi terhadap efektifitas tindakan keperawatan dan penelitian.

\section{E. Prinsip Penilaian Kinerja}

Untuk mengevaluasi bawahan secara tepat dan adil, manajer sebaiknya mengamati prinsip - prinsip tertentu (Gillies, 1996), yaitu :

1. Evaluasi pekerja sebaiknya didasarkan pada standar pelaksanaan kerja dan orientasi tingkah laku untuk posisi yang ditempati (Rombert, 1986 dikutip Gillies , 1996). Karena diskripsi kerja dan standar pelaksanaan kerja disajikan ke pegawai selama masa orientasi sebagai tujuan yang harus diusahakan. Pelaksanaan kerja sebaiknya dievaluasi berkenaan dengan sasaran - sasaran yang sama.

2. Sampel tingkah laku perawat yang cukup representatiif sebaiknya diamati dalam rangka evaluasi pelaksanaan kerjanya. Perhatian harus diberikan untuk mengevaluasi konsistensi tingkah laku serta guna menghindari hal yang tidak diinginkan. 
3. Perawat sebaiknya diberi salinan deskripsi kerja, standar pelaksanan kerja, dan bentuk evaluasi untuk peninjauan ulang sebelum pertemuan evaluasi sehingga baik perawat maupun supervisor dapat mendiskusikan evaluasi dari kerangka kerja yang sama.

4. Didalam menuliskan penilaian pelaksanaan kerja pegawai, manajer sebaiknya menunjukkan segi kepuasan kerja dan keperluan perbaikan. Supervisor sebaiknya merujuk pada contoh khusus mengenai tingah laku yang memuaskan maupun yang tidak memuaskan supaya dapat menjelaskan dasar komentar yang bersifat evaluatif.

5. Jika diperlukan, manajer sebaiknya menjelaskan area priopritas seiring dengan usaha perawat untuk meningkatkan pelaksanaan kerja.

6. Pertemuan evaluasi sebaiknya dilakukan pada waktu yang cocok bagi perwat dan manajer, diskusi evaluasi sebaiknya dilakukan dalam waktu yang cukup bagi keduanya.

7. Baik laporan evaluasi maupun pertemuan sebaik nya disusun dengan terencana sehingga perawat tidak merasa kalau pelaksanaan kerjanya sedang dianalisa (Simpson, 1985 dikutip Gillies, 1996).

\section{F. Proses Penilaian Kinerja}

Proses penyusunan penilaian kinerja menurut Mondy dan Noe (1993:398) terbagi dalam beberapa tahapan kegiatan yang ditunjukkan dalam gambar di bawah ini:

Gambar 2.2 Proses Penilaian Kinerja (Mondy dan Noe, 1993)

Langkah pertama yang harus dilakukan dalam menyusun sistem penilaian kinerja yaitu harus digali terlebih dahulu tujuan yang ingin dicapai oleh organisasi dengan adanya sistem penilaian kinerja yang akan disusun. Hal ini menjadi penting karena dengan mengetahui tujuan yang ingin dicapai akan lebih memudahkan dalam menentukan desain penilaian kinerja. 


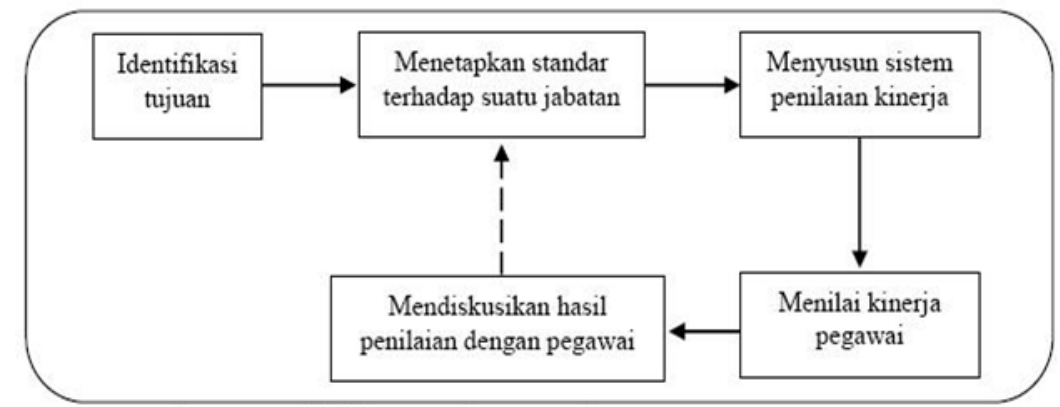

Gambar Proses Penilaian Kinerja (Mondy dan Noey, 1993)

Langkah yang kedua, menetapkan standar yang diharapkan dari suatu jabatan, sehingga akan diketahui dimensi yang akan diukur dalam penilaian kinerja. Dimensi tersebut tentunya harus sangat terkait dengan pelaksanaan tugas pada jabatan itu. Tahap ini biasanya dapat dilakukan dengan menganalisa jabatan (job analysis) atau menganalisa uraian tugas masing-masing jabatan.

Setelah tujuan dan dimensi yang akan diukur dalam penilaian kinerja diketahui, maka langkah selanjutnya yaitu menentukan desain yang sesuai untuk mencapai tujuan yang diharapkan. Penentuan desain penilaian kinerja ini harus selalu dikaitkan dengan tujuan penilaian. Hal ini karena setiap desain penilaian kinerja memiliki kelemahan dan kelebihan. Sebagai contoh, penilaian kinerja yang dilakukan untuk menentukan besaran gaji pegawai dengan penilaian kinerja yang bertujuan hanya untuk mengetahui kebutuhan pengembangan pasti memiliki desain yang berbeda.

Langkah berikutnya adalah melakukan penilaian kinerja terhadap pegawai yang menduduki suatu jabatan. Penilaian kinerja ini dapat dilakukan oleh atasan saja, atau dengan sistem $360^{\circ}$. Penilaian dengan sistem $360^{\circ}$ maksudnya adalah penilaian satu pegawai dilakukan oleh atasan, rekan kerja yang sejajar/ setingkat, dan bawahan.

Hasil dari penilaian kinerja, selanjutnya dianalisa dan 
dikomunikasikan kembali kepada pegawai yang dinilai agar mereka mengetahui kinerjanya selama ini serta mengetahui kinerja yang diharapkan oleh organisasi. Evaluasi terhadap sistem penilaian kinerja yang telah dilakukan juga dilaksanakan pada tahap ini.

Mejia (2004) dalam Harianto (2014) mengungkapkan bahwa proses penilaian kinerja terdiri dari :

1. Identifikasi, yaitu menentukan faktor - faktor kinerja yang berpengaruh terhadap kesuksesan suatu organisasi. Hal ini dapat dilakukan dengan mengacu pada hasil analisis jabatan

2. Pengukuran, merupakan inti dari proses sistem penilaian kinerja. Pihak manajemen menentukan kinerja pegawai yang termasuk baik dan buruk. Manajemen dalam suatu organisasi harus melakukan perbandingan dengan nilai nilai standar atau memperbandingkan kinerja antar pegwai yang memiliki kesamaan tugas.

3. Manajemen, proses ini merupakan tindak lanjut dari hasil penilaian kinerja. Pihak manajemen harus berorientasi ke masa depan untuk meningkatkan potensi pegawai di organisasi bersangkutan. Hal ini dapat dilakukan dengan pemberian umpan balik dan pembinaan untuk meningkatkan kinerja pegawai.

\section{G. Metode Penilaian Kinerja}

Ada dua jenis metode penilaian kinerja menurut Werther dan Davis, (1996:350) yaitu past oriented appraisal methods (penilaian kinerja yang berorientasi pada masa lalu) dan future oriented appraisal methods (penilaian kinerja yang berorientasi ke masa depan).

1. Past based methods adalah penilaian kinerja atas kinerja seseorang dari pekerjaan yang telah dilakukannya. Kelebihan metode ini adalah jelas dan mudah diukur, terutama secara kuantitatif.Kekurangan metode ini adalah kinerja yang diukur tidak dapat diubah sehingga terkadang justru salah menunjukkan seberapa besar potensi yang dimiliki oleh seseorang. Selain itu, metode ini kadang sangat 
subyektif dan banyak bias.

2. Future based methods adalah penilaian kinerja dengan menilai besar potensi pegawai dan mampu untuk menetapkan kinerja yang diharapkan pada masa datang. Metode ini juga masih menggunakan past method. Catatan kinerja juga masih digunakan sebagai acuan untuk menetapkan kinerja yang diharapkan. Kekurangan dari metode ini adalah keakuratan, ketidakpastian proses kinerja seseorang pada masa datang.

Pengklasifikasian pendekatan penilaian kinerja oleh Wherther di atas berbeda dengan klasifikasi yang dilakukan oleh Kreitner dan Kinicki (2000). Berdasarkan aspek yang diukur, Kreitner dan Kinicki mengklasifikasikan penilaian kinerja menjadi tiga, yaitu: pendekatan trait, pendekatan perilaku dan pendekatan hasil.

1. Pendekatan trait adalah pendekatan penilaian kinerja yang lebih fokus pada orang. Pendekatan ini melakukan perankingan terhadap trait atau karakteristik individu seperti inisiatif, loyalitas dan kemampuan pengambilan keputusan. Pendekatan trait memiliki kelemahan karena ketidakjelasan kinerja secara nyata.

2. Pendekatan perilaku, pendekatan ini lebih fokus pada proses dengan melakukan penilaian kinerja berdasarkan perilaku yang tampak dan mendukung kinerja seseorang.

3. Pendekatan hasil adalah pendekatan yang lebih fokus pada capaian atau produk. Metode penilaian kinerja yang menggunakan pendekatan hasil seperti metode management by objective (MBO) (Kreitner dan Kinicki, 2000:303-304).

Metode-metode penilaian kinerja menurut Mondy dan Noe (1993:402-414) adalah:

4. Written Essays, merupakan teknik penilaian kinerja yaitu evaluator menulis deskripsi mengenai kekuatan pekerja, kelemahan, kinerja masa lalu, potensi dan memberikan sara untuk pengembangan pekerja.

5. Critical Incidents, merupakan teknik penilaian kinerja yaitu 
evaluator mencatat mengenai perilaku/ pencapaian terbaik dan terburuk (extremely good or bad behaviour) pegawai.

6. Graphic Rating Scales, merupakan teknik penilaian kinerja yaitu evaluator menilai kinerja pegawai dengan menggunakan skala dalam mengukur faktor kinerja (performance factor). Metode ini merupakan metode umum yang paling banyak digunakan oleh organisasi.

7. Behaviourally Anchored Rating Scales (BARS), merupakan teknik penilaian kinerja yaitu evaluator menilai pegawai berdasarkan beberapa jenis perilaku kerja yang mencerminkan dimensi kinerja dan membuat skalanya.

8. Multiperson Comparison, merupakan teknik penilaian kinerja yaitu seorang pegawai dibandingkan dengan rekan kerjanya. Biasanya dilakukan oleh supervisor. Ini sangat berguna untuk menentukan kenaikan gaji (merit system), promosi, dan penghargaan perusahaan.

9. Management By Objectives. Metode ini juga merupakan penilaian kinerja, yaitu pegawai dinilai berdasarkan pencapaiannya atas tujuan spesifik yang telah ditentukan sebelumnya. Tujuan ini tidak ditentukan oleh manajer saja. melainkan ditentukan dan disepakati bersama oleh para pegawai dan manajer.

\section{H. Outcomes Evaluasi Kinerja}

Ada tiga komponen outcomes evaluasi kinerja dalam organisasi, yaitu :

1. Clinical outcomes

Clinical outcomes berfokus pada penilaian proses asuhan sebagai perkembangan klien melalui suatu sistem yang luas dan spesifik. Umumnya penilaian harus memenuhi outcomes yang mungkin dapat diterapkan dalam pelayanan. Contoh indikator clinical outcomes adalah :

a. Angka infeksi. Outcome yang diharapkan harus bermakna seperti penurunan infeksi nasokomial menjadi nol.

b. Klien jatuh/ kecelakaan. Outcome yang diharapkan nol, 
berarti klien harus sering diobservasi terutama pada klien yang siap ambulansi.

\section{Administrative outcomes}

Outcomes ini khusus berkaitan dengan organisasi sebagai keseluruhan dan mempengaruhi sistem kepegawaian, staf, dokter dan alur bawah organisasi. Dasar pengukuran indikator dalam sistem pelayanan kesehatan adalah implikasi dari organisasi seperti :

a. Kepuasan pegawai. Ini merupakan indikator kritis dari outcome untuk keberhasilan program dan asuhan klien. Sistem ini harus meningkatkan kualitas lingkungan kerja pegawai meskipun membutuhkan waktu. Sistem yang lebih efektif dan efisien didasarkan pada filosofi kerja kelompok dan asuhan yang berfokus pada klien. Mengukur kepuasan pegawai harus dikaji atas peratuaran yang mendasar.

b. Analisis budaya dan suasana organisasi. Suatu perencanaan yang baik dan efektif dirancang dengan proses keseinambungan. Patokan kasus umum memberi implikasi positif baik terhadap budaya maupun suasana organisasi. Budaya membangun "spirit kelompok" dengan berfokus pada klien dan proses. Ini adalah nilai nyata adanya pendidikan dimana belajar menghargai diantara sesama staf, dokter dan manajemen. Transformasi suasana ke dalam lingkungan ini menumbuhkan autonomi staf, mendorong, menghargai kreativitas dan inovasi, mendukung kemampuan manajerial dan suatu kebersamaan diantara anggota kelompok.

\section{Service/ delivery outcomes}

Ada satu komponen tetap dari indikator pelayanan dasar yang dapat dievaluasi dan langsung menilai outcomes. Indikator outcomes pelayanan sedikit dan lebih sederhana, antara lain :

a. Kepuasan klien. Banyak metoda dan alat yang cocok 
untuk menilai kepuasan klien yang akurat sebagai indikator kritis. Kegagalan mendengar dan menanggapi persepsi klien dalam sistem pemberian asuhan akan mengakibatkan ancaman kegagalan dari organisasi. Data yang berkaitan dengan kepuasan klien harus disampaikan kepada semua staf secara regular, hanya outcomes terbaik memberikan "inovasi" lebih jauh untuk meningkatkan kinerja .

b. Penilaian yang kurang akan memberi dampak kepada organisasi.

c. Lamanya menunggu (Respone Time). Adalah indikator pelayanan yang sempurna untuk menilai efektivitas sistem. Suatu birokrasi yang kompleks, lamban, aturan sistem menghasilkan keterlambatan pemasaran. Klien sensitif terhadap keterlambatan dan keterbelakangan yang menimbulkan kesan negatif terhadap organisasi berdasarkan pengalaman dalam proses sewaktu masuk ke rumah sakit.

\section{Hambatan dalam Penilaian Kinerja}

Penilaian kinerja harus bebas dari diskriminasi. Bentuk atau metode penilaian yang dilakukan oleh pihak manajemen harus adil, realistis, valid, dan relevan dengan jenis pekerjaan yang akan dinilai. Penilaian kinerja tidak hanya berkaitan dengan masalah prestasi semata, namun juga menyangkut masalah gaji, hubungan kerja, promosi/demosi, dan penempatan pegawai. Adapun bias yang sering muncul menurut Werther dan Davis (1996:348) adalah:

1. Hallo Effect, terjadi karena penilai menyukai atau tidak menyukai sifat pegawai yang dinilainya. Oleh karena itu, pegawai yang disukai oleh penilai cenderung akan memperoleh nilai positif pada semua aspek penilaian, dan begitu pula sebaliknya, seorang pegawai yang tidak disukai akan mendapatkan nilai negatif pada semua aspek penilaian;

2. Liniency and Severity Effect. Liniency effect ialah penilai 
cenderung beranggapan bahwa mereka harus berlaku baik terhadap pegawai, sehingga mereka cenderung memberi nilai yang baik terhadap semua aspek penilaian. Sedangkan severity effect ialah penilai cenderung mempunyai falsafah dan pandangan yang sebaliknya terhadap pegawai sehingga cenderung akan memberikan nilai yang buruk;

3. Central tendency, yaitu penilai tidak ingin menilai terlalu tinggi dan juga tidak terlalu rendah kepada bawahannya (selalu berada di tengah). Toleransi penilai yang terlalu berlebihan tersebut menjadikan penilai cenderung memberikan penilaian dengan nilai yang rata-rata;

4. Assimilation and differential effect. Assimilation effect, yaitu penilai cenderung menyukai pegawai yang mempunyai ciri atau sifat seperti mereka, sehingga akan memberikan nilai yang lebih baik dibandingkan dengan pegawai yang tidak memiliki kesamaan sifat dan ciri dengannya. Sedangkan differential effect, yaitu penilai cenderung menyukai pegawai yang memiliki sifat atau ciri yang tidak ada pada dirinya, tapi sifat itulah yang mereka inginkan, sehingga penilai akan memberinya nilai yang lebih baik dibanding yang lainnya;

5. First impression error, yaitu penilai yang mengambil kesimpulan tentang pegawai berdasarkan kontak pertama mereka dan cenderung akan membawa kesan ini dalam penilaiannya hingga jangka waktu yang lama;

6. Recency effect, penilai cenderung memberikan nilai atas dasar perilaku yang baru saja mereka saksikan, dan melupakan perilaku yang lalu selama suatu jangka waktu tertentu. 


\section{BAB IV TEORI CARING}

\section{A. Teori Caring Kristen M. Swanson}

Teori caring Swanson (1993) diawali dalam penemuan wawancaranya yang dilakukannya pada wanita yang mengalami keguguran, orangtua yang memiliki anak di unit perawatan intensif, dan ibu yang secara sosial berisiko dan telah melalui system untuk menerima berbagai macam bentuk perawatan kesehatan (Potter et al. 2005). Kristen M. Swanson mampu memahami ruang lingkup caring secara keseluruhan dan pada saat yang sama menguraikan dimensi spesifik dari keperluan seorang perawat untuk merawat klien. Salah satu hal paling penting yang memberikan kontribusi pada teori keperawatan dalam hal ini yaitu argumen bahwa klien seharusnya tidak hanya dilihat sebagai individu yang terpisah, melainkan sebagai manusia seutuhnya. Hal yang menarik tentang pengertian klien ini adalah bahwa Swanson selalu menempatkan peran perawat dalam proses becoming tersebut. Jadi dalam aspek kesehatan becoming tersebut, perawat tidak hanya menjadi dispenser pengobatan medis, tetapi juga merupakan mitra dalam membantu klien lebih dekat dengan tujuannya untuk mensejahterakan klien (well-being).

Teori caring Swanson menyajikan permulaan yang baik untuk memahami kebiasaan dan proses karakteristik pelayanan. Teori caring Swanson menjelaskan tentang proses caring yang terdri dari proses perawat mengerti kejadian yang berarti di dalam hidup seseorang, hadir secara emosional, melakukan suatu hal kepada orang lain sama seperti melakukan terhadap diri sendiri, memberi informasi dan memudahkan jalan seseorang dalam menjalani transisi kehidupan serta menaruh kepercayaan seseorang dalam menjalani hidupnya. 
Swanson (1993) menjelaskan middle range theory of caring. Caring didefinisikan sebagai a nurturing way of relating to a valued other toward whom one feels a personal sense of commitment and responsibility. Kata kunci dari definisi tersebut adalah memberikan asuhan keperawatan yang bernilai kepada klien dengan penuh rasa komitment dan tanggung jawab (Potter \& Perry, 2009 : 112).

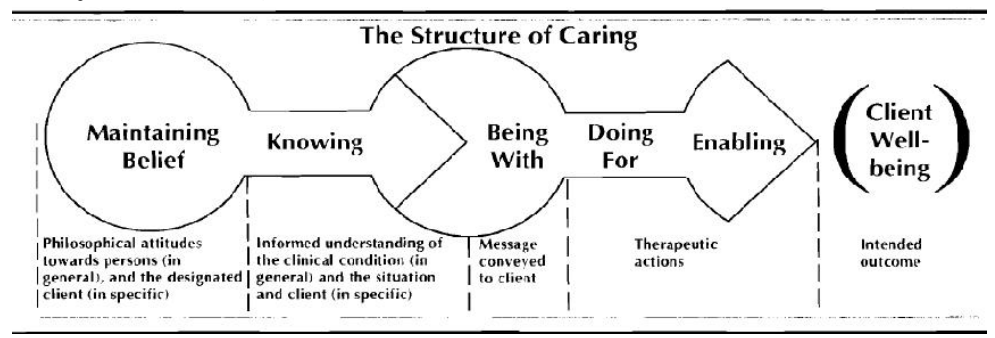

Gambar Struktur Caring Swanson (Potter \& Perry, 2009)

Asumsi dasar dari teori ini ditemukan dalam gagasan caring yang dijelaskan Swanson. Menurut Swanson, caring adalah proses multifaset yang terus ada dalam dinamika hubungan klien - perawat. Ada yang melihat proses ini sebagai hubungan yang linear, namun juga harus dianggap sebagai hubungan siklik, dan proses yang terjadi harus selalu diperbarui karena peran perawat untuk membantu klien mencapai kesehatan dan kesejahteraan.

Secara umum, proses yang terjadi sebagai berikut, pertama perawat membantu klien mempertahankan keyakinannya, yang berarti bahwa perawat mendorong klien dan membantu untuk memperkuat harapan mereka mengatasi kesulitan saat ini. Hal ini sangat penting terutama dalam kasus di mana klien menghadapi penyakit yang mengancam nyawa seperti kanker, atau peristiwa yang sangat traumatis seperti keguguran (Wojnar, D.M., \& Swanson, K. M., 2004). 
Sebagai pelengkap dan langkah berikutnya dalam proses untuk mempertahankan keyakinan, adalah knowing. Dalam proses knowing, perawat berusaha untuk memahami apa arti situasi yang terjadi saat ini bagi klien, hal ini muncul dalam bentuk latihan sebagai seorang perawat, yang menciptakan seseorang dengan rasa tertentu bagaimana kondisi fisik dan psikologis dapat mempengaruhi seseorang secara keseluruhan. Dengan mengetahui apa yang dialami klien, perawat kemudian dapat melanjutkan proses do for, ada untuk memberikan tindakan terapi dan intervensi bagi klien. Proses do for, diikuti dengan proses enabling yang memungkinkan klien untuk mencapai kesehatan dan kesejahteraannya (well being).

Swanson mengidentifikasi 3 tipe kondisi penyebab caring, yaitu klien, perawat dan organisasi. Kondisi organisasi meliputi beberapa komponen dari Profesional Practice Model (PPM) yaitu : (1) kepemimpinan, (2) kompensasi dan penghargaan, serta (3) Hubungan profesional. Apabila 3 komponen ini diciptakan dalam lingkungan kerja akan mendukung dalam praktek caring dalam pelayanan. (Tonges \& Ray, 2011)

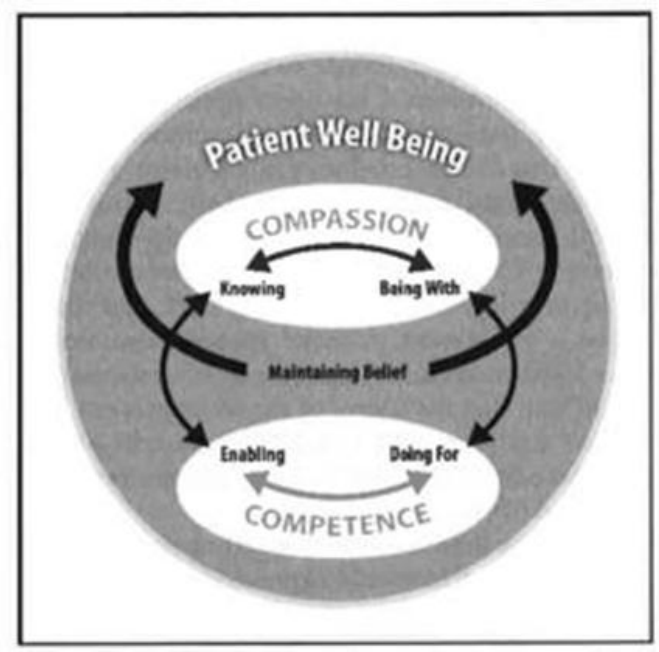

Gambar Caring Swanson : Framing the Culture of Carolina Care (Tonges \& Ray, 2011) 
Seperti ilustrasi dalam gambar di atas menjelaskan bahwa dalam proses caring, dipelajari secara mendalami tentang budaya (maintaining belief), mengkombinasi pengetahuan dengan rasa kasihan (knowing and being with) dan kompetensi (doing for dan enablings), dengan hasil akhir (outcomes) untuk menyembuhkan klien dan meningkatkan kesejahteraan klien (Tonges \& Ray, 2011).

\section{B. Dimensi Caring Menurut Kristen Swanson}

Ada lima dimensi yang mendasari konsep Caring, yaitu :

\section{Maintaining Belief}

Maintaining Belief yaitu menumbuhkan keyakinan seseorang dalam melalui setiap peristiwa hidup dan masamasa transisi dalam hidupnya serta menghadapi masa depan dengan penuh keyakinan, meyakini kemampuan orang lain, menumbuhkan sikap optimis, membantu menemukan arti atau mengambil hikmah dari setiap peristiwa, dan selalu ada untuk orang lain dalam situasi apa pun. Tujuannya adalah untuk memungkinkan orang lain terbantu dalam batas-batas kehidupannya sehingga mampu menemukan makna dan mempertahankan sikap yang penuh harapan. Memelihara dan mempertahankan keyakinan nilai hidup seseorang adalah dasar dari caring dalam praktek keperawatan. Subdimensi:

\section{a. Believing in}

Perawat menanggapi apa yang klien rasakan dan percaya bahwa perasaan - perasaan tersebut bisa terjadi dan wajar terjadi pada siapapun yang sedang dalam masa transisi.

\section{b. Offering a hope - filled attitude}

Menunjukkan perilaku bahwa perawat sepenuhnya peduli/care terhadap masalah yang dialami dengan sikap tubuh, kontak mata dan intonasi bicara perawat. 


\section{c. Maintaining realistic optimism}

Menjaga dan menunjukan optimisme perawat dan harapan terhadap apa yang menimpa klien secara realistis dan berusaha mempengaruhi agar klien mempunyai optimisme dan harapan yang sama.

d. Helping to find meaning

Membantu klien menemukan makna akan masalah yang terjadi sehingga klien perlahan - lahan menerima bahwa setiap orang dapat mengalami apa yang dialami klien.

\section{e. Going the distance (menjaga jarak)}

Semakin jauh menjalin/menyelami hubungan dengan tetap menjaga hubungan sebagai perawat-klien yang tujuan akhir dalam tahap ini adalah kepercayaan klien sepenuhnya terhadap perawat dan responsibility serta caring secara total oleh perawat kepada klien.

\section{Knowing}

Knowing adalah berjuang untuk memahami peristiwa yang memiliki makna dalam kehidupan klien. Mempertahankan kepercayaan adalah dasar dari caring keperawatan, knowing adalah memahami pengalaman hidup klien dengan mengesampingkan asumsi perawat mengetahui kebutuhan klien, menggali/menyelami informasi klien secara detail, sensitive terhadap petunjuk verbal dan non verbal, fokus kepada satu tujuan keperawatan, serta melibatkan orang yang memberi asuhan dan orang yang diberi asuhan dan menyamakan persepsi antara perawat dan klien. Knowing adalah penghubung dari keyakinan keperawatan terhadap realita kehidupan. Subdimensi:

\section{a. Avoiding assumptions}

Menghindari asumsi-asumsi

\section{b. Assessing thoroughly}

Melakukan pengkajian menyeluruh meliputi bio, psiko, social, spitual dan kultural 


\section{c. Seeking clues}

Perawat menggali informasi secara mendalam

\section{d. Centering on the one cared for}

Perawat berfokus pada klien dalam melakukan asuhan keperawatan

\section{e. Engaging the self of both}

Melibatkan diri sebagai perawat secara utuh dan bekerja sama dengan klien dalam melakukan asuhan keperawatan yang efektif

\section{Being With}

Being with maksudnya tidak hanya hadir secara fisik, tetapi juga komunikasi, berbagi perasaan tanpa beban dan secara emosional bersama klien dengan maksud menawarkan kepada klien dukungan, kenyamanan, pemantauan dan mengurangi intensitas perasaan yang tidak diinginkan.Subdimensi:

\section{a. Non-burdening}

Perawat bekerjasama dengan klien tanpa memaksa kehendak kepada klien dalam melakukan tindakan keperawatan

\section{b. Convering availability}

Menunjukan kesediaan perawat dalam membantu klien dan memfasilitasi klien untuk mencapai tahap kesejahteraan / well being.

c. Enduring with

Bersama-sama

\section{d. Sharing feelings}

Berbagi pengalaman bersama klien yang berkaitan dengan usaha peningkatan kesehatan klien. Being with perawat dapat menunjukkan dengan cara kontak mata, bahasa tubuh, nada suara, mendengarkan serta memiliki sikap positif dan bersemangat yang dilakukan perawat, akan membentuk sesuatu suasana keterbukaan dan saling mengerti. 


\section{Doing For}

Doing for berarti bekerja sama melakukan sesuatu tindakan yang bisa dilakukan, mengantisipasi kebutuhan yang diperlukan, kenyamanan, menjaga privasi dan martabat klien. Subdimensi:

a. Comforting (memberikan kenyamanan)

Dalam melakukan tindakan keperawatan dilakukan dengan memberikan kenyamanan pada klien dan menjaga privasi klien.

b. Performing competently (menunjukkan ketrampilan)

Tidak hanya berkomunikasi dan memberikan kenyaman dalam tindakannya, perawat juga menunjukkan kompetensi atau skill sebagai perawat professional

c. Preserving dignity (menjaga martabat klien)

Menjaga martabat klien sebagai individu atau memanusiakan manusia.

\section{d. Anticipating ( mengantisipasi )}

Perawat dalam melakukan tindakan selalu meminta persetujuan klien dan keluarga

e. Protecting (melindungi)

Melindungi hak-hak klien dalam memberikan asuhan keperawatan dan tindakan medis

\section{Enablings}

Enabling adalah memampukan atau memberdayakan klien, memfasilitasi klien untuk melewati masa transisi dalam hidupnya dan melewati setiap peristiwa dalam hidupnya yang belum pernah dialami dengan memberi informasi, menjelaskan, mendukung dengan focus masalah yang relevan, berfikir melalui masalah dan menghasilkan alternative pemecahan masalah sehingga meningkatkan penyembuhan klien atau klien mampu melakukan tindakan yang tidak biasa dia lakukan dengan cara memberikan dukungan, memvalidasi perasaan dan memberikan umpan balik / feedback. 
Subdimensi:
a. Validating (memvalidasi)
Memvalidasi semua tindakan yang telah dilakukan
b. Informing ( memberikan informasi)

Memberikan informasi yang berkaitan dengan peningkatan kesehatan klien dalam rangka memberdayakan klien dan keluarga klien.

\section{c. Supporting (mendukung)}

Memberikan dukungan kepada klien dalam mencapai kesejahteraan / well being sesuai kapasitas sebagai perawat

\section{d. Feedback (memberikan umpan balik)}

Memberikan umpan balik terhadap apa yang dilakukan oleh klien dalam usahanya mencapai kesembuhan / well being

e. Helping patients to focus generate alternatives (membantu klien untuk fokus dan membuat alternatif) Menolong klien untuk selalu fokus dan terlibat dalam program peningkatan kesehatannya baik tindakan keperawatan maupun tindakan medis (Potter \& Perry, 2005).

\section{Perilaku Caring dalam Praktik Keperawatan}

Pandangan Swanson (1993) tentang keperawatan adalah siapa yang kita layani, bagaimana kita memberikan pelayanan dan kenapa kita terus untuk melayani merupakan keharusan bagi perawat untuk dapat mengintegrasikan ilmu pengetahuan, diri sendiri, fokus pada kemanusian dan caring. Yang kemudian disempurnakan dengan adanya transaksi antara keperawatan, setiap perawat dan klien bahwa perawat adalah profesi yang memiliki komitmen caring, pemeliharan akan martabat manusia dan meningkatkan kesehatan (Alligood, 2010).

Swanson (1993) mempelajari tentang klien dan profesi pemberi layanan dalam usahanya untuk membuat teori tentang caring dalam praktik keperawatan yang bermanfaat dalam memberikan petunjuk bagaimana membangun strategi caring 
yang berguna dan efektif. Teori caring Swanson ini juga menyajikan permulaan yang baik untuk memahami kebiasaan dan proses karakteristik pelayanan yang berisi lima kategori atau proses.

Caring secara umum dapat diartikan sebagai suatu kemampuan untuk berdedikasi bagi orang lain, pengawasan dengan waspada, perasaan empati pada orang lain dan perasaan cinta atau menyayangi. Caring adalah sentral untuk praktik keperawatan karena caring merupakan suatu cara pendekatan yang dinamis, dimana perawat bekerja untuk lebih meningkatkan kepeduliannya kepada klien. Dalam keperawatan, caring merupakan bagian inti yang penting terutama dalam praktik keperawatan (Sartika, 2010 dalam Hayati, 2014).

Tindakan caring bertujuan untuk memberikan asuhan fisik dan memperhatikan emosi sambil meningkatkan rasa aman dan keselamatan klien. Caring juga menekankan harga diri individu, artinya dalam melakukan praktik keperawatan, perawat senantiasa selalu menghargai klien dengan menerima kelebihan maupun kekurangan klien sehingga bisa memberikan pelayanan kesehatan yang tepat. Penilaian terhadap seorang perawat dapat terlihat dari perilaku caring yang dimiliki perawat. Teori Caring Swanson menyajikan permulaan yang baik untuk memahami kebiasaan dan proses karakteristik pelayanan. Teori Caring Swanson (1993) menjelaskan tentang proses Caring yang terdiri dari bagaimana perawat mengerti kejadian yang berarti di dalam hidup seseorang, hadir secara emosional, melakukan suatu hal kepada orang lain sama seperti melakukan terhadap diri sendiri, memberi informasi dan memudahkan jalan seseorang dalam menjalani transisi kehidupan serta menaruh kepercayaan seseorang dalam menjalani hidup (Potter \& Perry, 2009 : 112). 


\section{BAB V STANDARISASI SISTEM PENILAIAN KINERJA PERAWAT BERBASIS CARING}

\section{A. Pedoman Penyusunan SOP (Standar Operasional Prosedur) dan Alur (Flowchart)}

Pedoman Penyusunan SPO berdasarkan Peraturan Menteri Pendayagunaan Aparatur Negara dan Reformasi Birokrasi Nomor 35 Tahun 2012 merupakan pedoman/ acuan bagi instansi pemerintah pusat dan pemerintah daerah provinsi/ kabupaten/ kota untuk menyusun Standar Operasional Prosedur Administrasi Pemerintahan (selanjutnya disebut SOP AP) di lingkungan instansi masing-masing dalam rangka pelaksanaan Reformasi Birokrasi.

\section{B. Pengertian SOP}

Standar Operasional Prosedur adalah serangkaian instruksi tertulis yang dibakukan mengenai berbagai proses penyelenggaraan aktivitas organisasi, bagaimana dan kapan harus dilakukan, dimana dan oleh siapa dilakukan.

\section{Manfaat SOP}

a. Sebagai standarisasi cara yang dilakukan aparatur dalam menyelesaikan pekerjaan yang menjadi tugasnya;

b. Mengurangi tingkat kesalahan dan kelalaian yang mungkin dilakukan oleh seorang aparatur atau pelaksana dalam melaksanakan tugas;

c. Meningkatkan efisiensi dan efektivitas pelaksanaan tugas dan tanggung jawab individual aparatur dan organisasi secara keseluruhan;

d. Membantu aparatur menjadi lebih mandiri dan tidak tergantung pada intervensi manajemen, sehingga akan mengurangi keterlibatan pimpinan dalam pelaksanaan proses sehari-hari;

e. Meningkatkan akuntabilitas pelaksanaan tugas 
f. Menciptakan ukuran standar kinerja yang akan memberikan aparatur cara konkrit untuk memperbaiki kinerja serta membantu mengevaluasi usaha yang telah dilakukan;

g. Memastikan pelaksanaan tugas penyelenggaraan pemerintahan dapat berlangsung dalam berbagai situasi;

h. Menjamin konsistensi pelayanan kepada masyarakat, baik dari sisi mutu, waktu, dan prosedur;

i. Memberikan informasi mengenai kualifikasi kompetensi yang harus dikuasai oleh aparatur dalam melaksanakan tugasnya;

j. Memberikan informasi bagi upaya peningkatan kompetensi aparatur;

k. Memberikan informasi mengenai beban tugas yang dipikul oleh seorang aparatur dalam melaksanakan tugasnya;

1. Sebagai instrumen yang dapat melindungi aparatur dari kemungkinan tuntutan hukum karena tuduhan melakukan penyimpangan;

$\mathrm{m}$. Menghindari tumpang tindih pelaksanaan tugas;

n. Membantu penelusuran terhadap kesalahan-kesalahan prosedural dalam memberikan pelayanan;

o. Membantu memberikan informasi yang diperlukan dalam penyusunan standar pelayanan, sehingga sekaligus dapat memberikan informasi bagi kinerja pelayanan

\section{Format SOP}

Format SOP AP yang dipersyaratkan dalam Kebijakan Reformasi Birokrasi memiliki format yang telah distandarkan tidak seperti format SOP pada umumnya. Adapun format SOP AP yang dipergunakan dalam Kebijakan Reformasi Birokrasi adalah sebagai berikut:

\section{Format Diagram Alir Bercabang (Branching Flowcharts)}

Format yang dipergunakan dalam SOP AP adalah format diagram alir bercabang (branching flowcharts) dan tidak ada format lainnya yang dipakai. Hal ini diasumsikan 
bahwa prosedur pelaksanaan tugas dan fungsi instansi pemerintah termasuk di dalamnya Kementerian/ Lembaga dan Pemerintah Daerah memuat kegiatan yang banyak (lebih dari sepuluh) dan memerlukan pengambilan keputusan yang banyak. Oleh sebab itu untuk menyamakan format maka seluruh prosedur pelaksanaan tugas dan fungsi administrasi pemerintahan dibuat dalam bentuk diagram alir bercabang (branching flowcharts) termasuk juga prosedur yang singkat (sedikit, kurang dari sepuluh) dengan/atau tanpa pengambilan keputusan.

\section{Menggunakan hanya Lima Simbol Flowcharts}

Simbol yang digunakan dalam SOP AP hanya terdiri dari 5 (lima) simbol, yaitu: 4 (empat) simbol dasar flowcharts (Basic Symbol of Flowcharts) dan 1 (satu) simbol penghubung ganti halaman (Off-Page Conector). Kelima simbol yang dipergunakan tersebut adalah sebagai berikut:

a. Simbol Kapsul/Terminator untuk mendeskripsikan kegiatan mulai dan berakhir;

b. Simbol kotak/ Process untuk mendeskripsikan proses atau

c. kegiatan eksekusi;

d. Simbol Belah ketupat/ Decision untuk mendeskripsikan kegiatan pengambilan keputusan;

e. Simbol anak panah/panah/ Arrow untuk mendeskripsikan arah

f. kegiatan (arah proses kegiatan);

g. Simbol segilima/ off - page connector untuk mendeskripsikan hubungan antar simbol yang berbeda halaman

\section{Pelaksana dipisahkan dari kegiatan}

Penulisan pelaksana dalam SOP ini dipisahkan dari kegiatan. Oleh karena itu untuk menghindari pengulangan 
yang tidak perlu dan tumpang- tindih (overlapping) yang tidak efisien maka penulisan kegiatan tidak disertai dengan pelaksana kegiatan (aktor) dan dipisahkan dalam kolom pelaksana tersendiri. Dengan demikian penulisan kegiatan menggunakan kata kerja aktif yang diikuti dengan obyek dan keterangan Penulisan pelaksana (aktor) tidak diurutkan secara hierarki tetapi didasarkanpada sekuen kegiatan sehingga kegiatan selalu dimulai dari sisi kiri dan tidak ada kegiatan yang dimulai dari tengah maupun sisi kanan dari matriks flowcharts.

\section{Flowchart}

Flowchart merupakan uraian mengenai langkah langkah (prosedur) kegiatan beserta mutu baku dan keterangan yang diperlukan. Bagian Flowchart ini berupa flowcharts yang menjelaskan langkah - langkah kegiatan secara berurutan dan sistematis dari prosedur yang distandarkan, yang berisi: Nomor kegiatan; Uraian kegiatan yang berisi langkah-langkah (prosedur); Pelaksana yang merupakan pelaku (aktor) kegiatan; Mutu Baku yang berisi kelengkapan, waktu, output dan keterangan.

\section{E. Langkah Penyusunan SOP}

Penyusunan SOP AP meliputi siklus sebagai berikut: (1) Persiapan; (2) Penilaian Kebutuhan SOP; (3) Pengembangan SOP; (4) Penerapan SOP dan (5) Monitoring dan Evaluasi SOP.

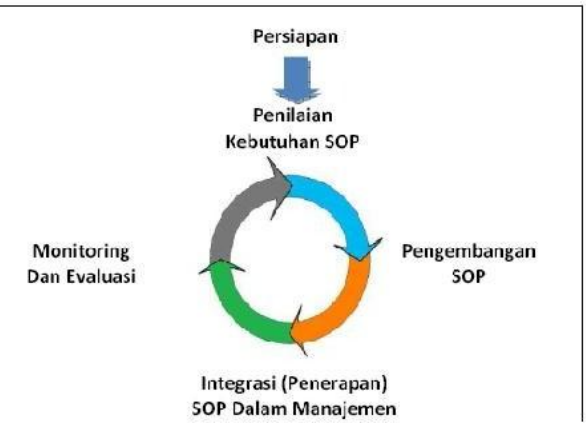

Gambar Siklus Penyusunan SOP 
Secara rinci tahapan penyusunan SOP AP melalui proses sebagai berikut

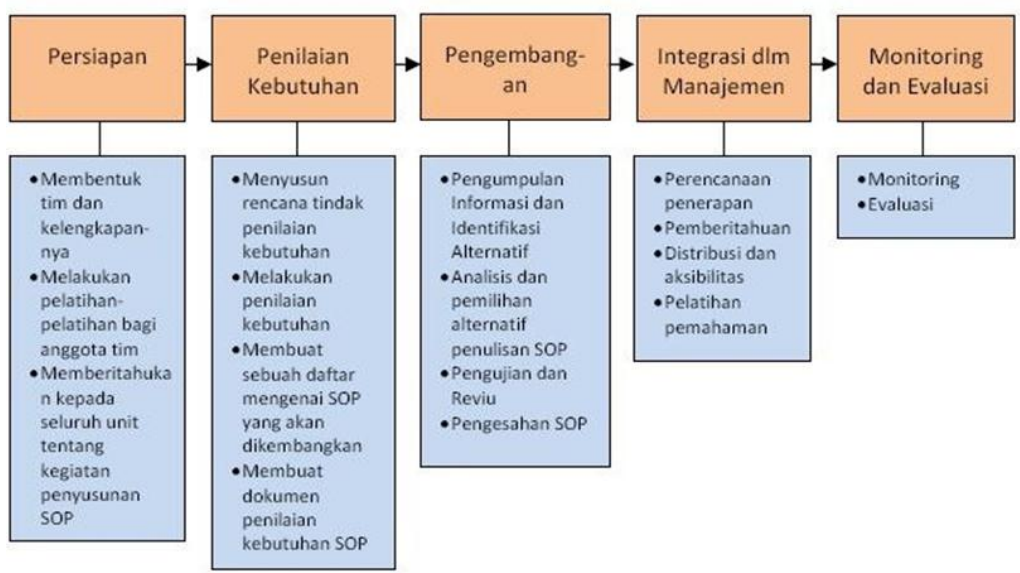

Gambar Rincian Tahapan Penyusunan SOP

\section{F. Instrumen Penilaian Kinerja Perawat Pelaksana Berbasis \\ Caring}

1. Komponen Penilaian

Instrumen penilaian kinerja perawat pelaksana berbasis caring terdiri dari dua komponen penilaian yaitu :

a. Sasaran Kinerja Perawat

Sasaran kinerja perawat berupa uraian tugas perawat pelaksana tentang kumpulan tugas karyawan yang ada di RS

b. Perilaku Kinerja Perawat Pelaksana berbasis Caring

Perilaku kinerja perawat pelaksana berdasarkan lima dimensi dalam teori caring Swanson.Komponen penilaian berupa 13 item sasaran kinerja perawat (uraian tugas perawat pelaksana) dan 10 item perilaku kerja berdasarkan 5 dimensi caring menurut Kristen Swanson (maintaining belief, knowing, being with, doing for dan enabling).

Dimensi maintaining belief dalam instrumen penilaian kinerja diterapkan dalam item penilaian komunikasi dan optimisme. Hal ini sesuai dengan sub dimensi maintaining 
belief yaitu perilaku yang menunjukkan bahwa perawat sepenuhnya peduli/care terhadap masalah yang dialami dengan sikap tubuh, kontak mata dan intonasi bicara perawat yang diterpakan dalam item penilaian komunikasi. Dalam penerapan item penilaian optimisme berdasarkan subdimensi maintaining belief yaitu menjaga dan menunjukan optimisme perawat dan harapan terhadap apa yang menimpa klien secara realistis.

Dimensi knowing dalam instrumen penilaian kinerja diterapkan dalam item penilaian uraian tugas sesuai dengan subdimensi assesing throughly yaitu melakukan pengkajian menyeluruh meliputu bio,psiko, social, spiritual dan kultural. Untuk item penilaian kerjasama dalam dimensi knowing berdasarkan subdimensi engaging the self of both yang berarti perawat melibatkan diri secara utuh dan bekerjasama dengan klien dalam melakukan asuhan keperawatan yang efektif.

Dimensi being with dalam instrumen penilaian kinerja diterapkan dalam item penilaian tanggap, koordinasi dan disiplin. Tanggap berdasarkan subdimensi convering availability yang menunjukkan kesediaan perawat dalam membantu klien dan memfasilitasi klien untuk mencapai tahap kesembuhan/ well being. Koordinasi ditunjukkan dalam dalam komitmen perawat dengan tim dalam usaha meningkatkan kesehatan klien serta disiplin adalah salah satu wujud penerapan komitmen dalam melakukan asuhan keperawatan kepada klien. Kedua hal tersebut sesuai dengan makna subdimensi enduring with dalam dimensi being with.

Dimensi doing for dalam instrumen penilaian kinerja diterapkan dalam item penilaian uraian tugas dan etika. Dalam dimensi doing for berarti melakukan tindakan keperawatan, mengantisipasi kebutuhan yang diperlukan klien, memberikan kenyamanan, serta menjaga privasi dan martabat klien teraplikasikan dalam item penilaian uraian tugas dan etika. 
Dimensi enabling dalam instrumen penilaian kinerja diterapkan dalam item penilaian motivasi dan inovatif. Enabling memiliki makna bahwa memampukan atau memberdayakan klien, memfasilitasi klien untuk melewati masa transisi dalam hidupnya dan melewati setiap peristiwa dalam hidupnya yang belum pernah dialami dengan memberi informasi, menjelaskan, mendukung dengan focus masalah yang relevan, berfikir melalui masalah dan menghasilkan alternative pemecahan masalah sehingga meningkatkan penyembuhan klien. Dalam memampukan dan memberdayakan klien, item penilaian motivasi dan inovatif mewakili dalam penerapakan dimensi enabling dalam penilaian kinerja perawat pelaksana.

\section{Bobot Penilaian}

Dalam instrumen penilaian kinerja perawat pelaksana berbasis caring, bobot untuk SKP (uraian tugas perawat pelaksana) adalah 40, dan perilaku kinerja berbasis caring adalah item caring dalam penilaian kinerja perawat pelaksana. Sesuai dengan proses penyusunan penilaian kinerja menurut Mondy dan Noe (1993) bahwa dalam menyusun sistem penilaian kinerja harus digali terlebih dahulu tujuan yang ingin dicapai oleh organisasi (rumah sakit) untuk lebih memudahkan dalam menentukan metode penilaian kinerja.

\section{Hasil atau nilai penilaian}

Hasil penilaian dihitung dari bobot dan target.

Target pencapaian item penilaian selama enam bulan terhitung melalui lembar observasi kinerja perawat. Hasil akhir berupa angka yang akan menunjukkan bagaimana kriteria kinerja perawat tersebut. Kategori penilaian kinerja perawat pelaksana berdasarkan PP No. 46 tahun 2011 tentang penilaian prestasi kerja PNS. Apabila hasil penilaian menunjukkan kinerja yang baik dan sangat baik akan mendapatkan reward yang telah disediakan oleh pihak manajemen RS. Sebaliknya apabila hasil penilaian 
menujukkan kinerja yang kurang akan mendapatkan pelatihan/ bimbingan dari pihak RS.

\section{Feedback}

Dalam penilaian kinerja dibutuhkan feedback atau umpan balik. Umpan balik merupakan proses tindak lanjut dari hasil penilaian kinerja yang bertujuan untuk meningkatkan potensi pegawai di organisasi bersangkutan (Mejia, 2004 dalam Harianto, 2014). Kalb et al. (2006) menambahkan bahwa instrumen penilaian kinerja juga harus efisien dan menyediakan umpan balik yang berarti bagi perawat. Umpan balik dalam instrumen penilaian kinerja perawat pelaksan ini merupakan rencana tindak lanjut pengembangan SDM yang harus diisi oleh penilai untuk menjadi wacana manajer Keperawatan memberikan rekomendasi kepada top manager dalam peningkatan SDM di RS.

Penilaian kinerja yang dilakukan dengan tepat dan objektif akan memberikan dampak bagi mutu asuhan keperawatan dan kepuasan klien. Dengan adanya penilaian kinerja perawat pelaksana akan memberikan motivasi perawat untuk memberikan kinerja (performa) terbaiknya sehingga mutu asuhan keperawatan dapat meningkat. Terlebih lagi unsur caring yang menjadi bagian penting dalam penilaian dimaksudkan sebagai upaya peningkatan interaksi antara perawat dengan klien. Selain mutu asuhan keperawatan yang memiliki dampak positif dengan diterapkannya sistem penilaian kinerja perawat pelaksana berbasis caring, bagi perawat sendiri memunculkan banyak manfaat. Hasil penilaian kinerja yang baik dan meningkat akan memberikan keuntungan bagi perawat dengan adanya sistem remunasi, peningkatan karir (promosi) yang berujung dengan peningkatan pendapatan perawat. 


\section{BAB VI \\ PENUTUP}

Instrumen penilaian kinerja perawat pelaksana berbasis caring hasil pengembangan ini memberikan motivasi perawat untuk memberikan kinerja (performa) terbaiknya. Unsur caring dalam semua indikator penilaian kinerja perawat pelaksana dalam instrumen ini menjadi bagian penting sebagai upaya peningkatan interaksi antara perawat dengan klien sehingga mutu asuhan keperawatan dapat meningkat. 


\section{DAFTAR PUSTAKA}

Alligood, M,. R. \& Tomey. A. M. (2010). Nursing theorist and their work.

Seventh Edition. St Louis, Missouri: Elseiver Mosby.

Budiarto, Eko. (2002). Metodologi Penelitian Kedokteran Sebuah Pengantar.

Jakarta : EGC Kedokteran. p.213-227.

Carson, E. M. (2004). Do performance appraisal of registered nurses reflect a relationship between hospital size and caring. Nursing Forum, 39 (1), 5-13.

Fatimah, Kadir, A.R. \& Nontji, W. (2013). Hubungan kompetensi, komitmen organisasi, dan kepuasan kerja dengan kinerja perawat di RSUD Labuang Baji. , (2).

Gibson, James., Ivancevich., \& Donnelly. (2012). Organizations : Behavior, Structure, Processes. Fourteenth Edition. New York : McGraw-Hill. p.374- 376.

_Gibson, James., Ivancevich., \& Donnelly. (2005). Organisasi : Perilaku, Struktur, Proses. Jilid 1-2. Edisi 5.Jakarta : Erlangga.

Gillies, D. A. (1996). Manajemen Keperawatan Suatu Pendekatan Sistem. Edisi Ke Dua. Jakarta.

Gonçalves, V. L. M., Lima, A. F. C., Crisitano, N., \& Hashimoto, M. R. K. (2007). The creation of performance evaluation indicators through a focus group. Revista Latino-Americana de Enfermagem, 15(1), 134-41. http://doi.org/10.1590/S010411692007000100020

Hafizurrachman, Trisnantoro, L., \& Bachtiar, A. (2012). Several Factors that Influence the Performance of Nurses in Carrying Out Nursing Policy in a District Hospital. J Indon Med Assc, 387-393. Retrieved from http://indonesia.digitaljournals.org/index.php/idnmed/ar ticle/view/1075

Hajinezhad, M. E., \& Azodi, P. (2014). Nurse Caring Behaviors from Patients ' and Nurses ' Perspective: A Comparative Study. European Online Journal of Natural and Social Sciences, 3(4), 1010-1017. 
Handoko, Hani. (2012). Manajemen Edisi 2. Yogyakarta : BPFE. p.150-151.

Hayati, K., (2014). Pengembangan Sistem Penilaian Kinerja Perawat Pelaksana di Rumah Sakit Umum Daerah Dr. Pringadi Medan. Tesis tidak dipublikasikan. Universitas Sumatera Utara.

Husaini, Usman. (2011). Manajemen: Teori, Praktik, dan Riset Pendidikan Jakarta: PT. Bumi Aksara.

Ilyas, Yaslis. (2002). Kinerja : Teori, Penilaian, dan Penelitian. Jakarta: Pusat Kajian Ekonomi Kesehatan FKM UI.

Indrizal, E. (2014). Diskusi Kelompok Terarah Focus Group Discussion (FGD) (Prinsip-Prinsip dan Langkah Pelaksanaan Lapangan). Padang : FISIP Universitas Andalas. 75-82.

Joonbakhsh, F. \& Pashaee, S., (2014). Caring Behaviors Perceived by Nurses and Students in Critical Care Units in Tabriz University of Medical Sciences Affiliated Hospitals. International Research Journal of Applied and basic Sciences, 8(4), pp.489-493.

Kementrian Kesehatan Republik Indonesia. UU No. 38 tahun 2014 tentang Keperawatan. Diakses dari http://www.innappni.or.id/index.php/component/content/article/85-berita/144undang- undang-keperawatan. Tanggal 28 Oktober 2015. Pukul 19:45 WIB.

Kementrian Pendayaguanaan Aparatur Negara dan Reformasi Birokrasi Republik Indonesia. Peraturan Menteri Pendayagunaan Aparatur Negara dan Reformasi Birokrasi Nomor 25 tahun 2014. Diakses melalui http://www.menpan.go.id/jdih/permen-kepmen/kepmenpan-rb. Tanggal 3 Nopember 2015. Pukul 20.00 WIB.

Peraturan Menteri Pendayagunaan Aparatur Negara dan Reformasi Birokrasi Nomor 35 Tahun 2012. Diakses melalui http://www.menpan.go.id/jdih/permen-kepmen/kepmenpan-rb.

Tanggal 27 Februari 2016. Pukul 12.30 WIB.

Kementerian Sekretariat Negara Republik Indonesia. Peraturan Pemerintah RI No. 46 Tahun 2011.Diakses melalui http://www.batan.go.id/prod_hukum/extern/PP-46- 
TAHUN-2011.pdf. Tanggal 13 Juli 2016. Pukul 20.00 WIB.

Kreitner, Robert dan Kinicki, Angelo. (2000). Perilaku Organisasi (Organizational Behavour). Edisi 5. Terjemah, Erly Suandy. Jakarta : Salemba Empat.

Kumajas, fisella W., Warouw, H. \& Bawotong, J., (2012).

Hubungan Karakteristik Individu dengan Kinerja Perawat di Ruang Rawat Inap Penyakit dalam RSUD Datoe Binagkang Kabupaten Bolaang Mongondow. , 33, pp.3-8.

Lusiani, Milawati. (2006). Hubungan Karakteristik Individu dan Sistem Penghargaan Kinerja Perawat Menurut Persepsi Perawat Pelaksana di RS Sumber Waras Jakarta. Tesis. Fakultas Ilmu Keperawatan Universitas Indonesia. Tesis tidak dipublikasikan.

Mangkunegara, A. (2005). Evaluasi Kinerja. Bandung : Refika Aditama.

Manuho, E., Warouw, H. \& Hamel, R., (2015). Hubungan Beban Kerja dengan Kinerja Perawat dalam Pemberian Asuhan Keperawatan di Instalasi Rawat Inap C1 RSUP Prof. Dr. R.D. Kandou Manado. eJournal Keperawatan, 3.

Mathis, R \& Jackson., (2002). Manajemen Sumber Daya Manusia, Edisi Pertama. Jakarta : Salemba Empat. (halaman : 75 - 113)

Muhith, A. (2013). Pengembangan Model Mutu Asuhan Keperawatan Berdasarkan Analisis Kinerja Perawat serta Kepuasan Klien. Disertasi tidak dapat dipublikasikan. Fakultas Kesehatan Masyarakat Universitas Airlangga Surabaya.

Moeheriono. (2009). Pengukuran Kinerja Berbasis Kompetensi. Bogor : Ghalia Indonesia.

Mondy, R.W., (2008). Manajemen Sumber Daya Manusia, Edisi Kesepuluh (terjemahan). Jakarta: Penerbit Erlangga.

Nursalam. (2015). Manajemen Keperawatan Aplikasi dalam Praktik Keperawatan Profesional. Edisi 5. Jakarta : Salemba Medika.

Nikpeyma, N., Abed, S. Z., Azargashb, E., \& Alavi, M. H. (2014). Problems of clinical nurse performance appraisal system: a qualitative study. Asian Nursing Research, 8(1),15-22. Availableat:http://www.ncbi.nlm.nih.gov/pubmed/250304 $\underline{88 .}$ 
Porter, C. a, Cortese, M., Vezina, M., \& Fitzpatrick, J. J. (2014). Nurse Caring Behaviors Following Implementation of a Relationship Centered Care Professional Practice Model. International Journal of Caring Sciences, 7(3), 818-822.

Potter \& Perry. (2009). Fundamental of nursing. Edisi Ke 7. Buku 1. Jakarta : EGC.

PPNI. (2005). Standar Praktek Profesional Perawat. Diakses dari http://www.inna-ppni.or.id. Tanggal 5 Nopember 2015. Pukul 21.15 WIB.

Rapin, J., Amour, D.D. \& Dubois, C., (2015). Indicators for Evaluating the Performance and Quality of Care of Ambulatory Care Nurses. , 2015.

Robbins, Stephen P.; Judge, Timothy A. (2008). Perilaku Organisasi Buku 1.Jakarta: Salemba Empat.

Sastradijaya, H.J. (2004). Faktor - faktor yang Berhubungan dengan Kinerja Perawat Rawat Inap RSUD Cilegon. Tesis. Fakultas Kesehatan Masyarakat Universitas Indonesia. Tesis tidak dipublikasikan.

Siagian, S.P. (2004). Manajemen Sumber Daya Manusia. Jakarta :

Bumi Aksara.

Siagian, S.P (2004). Teori Motivasi dan Aplikasinya. Jakarta : Rineka Cipta.

Siahaan, D.N. \& Tarigan, M., (2012). Kinerja Perawat dalam

Pemberian Asuhan Keperawatan di RS Tk II Putri Hijau

Medan. Jurnal Keperawatan Holistik, 1(2), pp.29 - 34.

Sugiyono. (2007). Metode Penelitian Kuantitatif, Kualitatif dan RED. Bandung: Alfabeta. p.274 - 276.

Sugiyono. (2012). Metode Penelitian Kuantitatif, Kualitatif dan RED. Bandung: Alfabeta. p.270.

Sulistyowati. (2012). Analisis Faktor - Faktor yang Mempengaruhi Pencapaian Target Kinerja Individu Perawat Pelaksana Berdasarkan Indeks Kinerja Individu di Gedung A RSU Pusat Nasional Dr. Cipto Mangunkusumo. Tesis. Fakultas Ilmu Keperawatan. Universitas Indonesia. Tesis tidak dipublikasikan. 
Swansburg, R.C. (2000). Pengantar Kepemimpinan dan Manajemen Keperawatan untuk Perawat Klinis. Alih bahasa, Suharyati Samba; Editor, Monica Ester. Jakarta: EGC.

Swanson. (1993). Nursing as Informed Caring for the Well Being of Others. IMAGE: Journal of Nursing Scholarship: 25(4). Retrieved from http:// www.son.washington.edu/

Tonges, M., \& Ray, J. (2011). Translating Caring Theory Into Practice. Journal of Nursing Administration.

Werther, W.B. \& Davis, K., (1996). Human Resources and Personnel Management, 5th Ed. Boston: McGraw-Hill.

Wijaya, Andi. (2013). Pengantar Riset Operasi. Jakarta : Mitra Wacana Media. Wojnar, D.M., \& Swanson, K. M. (2004). Optimal Healing Environments in Nursing. Journal of Alternative and Complementary Medicine, 10, s-43 - s- 48.

Zaghloul, A.A.Z. \& AlSokair, M.K., (2008). Constructing a nurse appraisal form: A Delphi technique study. Journal of Multidisciplinary Healthcare, 1(October), pp.114.Available at: http://www.ncbi.nlm.nih.gov/pubmed/21197327. 


\section{INSTRUMEN PENILAIAN KINERJA PERAWAT PELAKSANA BERBASIS CARING}

\begin{tabular}{|ll|ll|}
\hline Pejabat Penilai & & Perawat Pelaksana yang dinilai \\
Nama & $:$ & Nama & $:$ \\
NIP & $:$ & NIP & $:$ \\
Jabatan & $:$ & Jabatan & $:$ \\
Unit Kerja & $:$ & Unit Kerja & $:$ \\
\hline
\end{tabular}

\begin{tabular}{|c|c|c|c|c|c|}
\hline No & Komponen Penilaian Kinerja & Bobot & Target & $\begin{array}{c}\text { Hasil } \\
(\%)\end{array}$ & Skor \\
\hline 1. & \multicolumn{5}{|c|}{ Kinerja pelayanan (Uraian Tugas Perawat Pelaksana) } \\
\hline & Melakukan timbang terima klien & \multirow{12}{*}{40} & \multirow{12}{*}{100} & & \\
\hline & $\begin{array}{l}\text { Menerima klien baru dan memberikan } \\
\text { informasi berdasarkan format orientasi } \\
\text { klien dan keluarga (apabila kepala shift } \\
\text { tidak ada di tempat) }\end{array}$ & & & & \\
\hline & $\begin{array}{l}\text { Melakukan pengkajian secara bio,psiko, } \\
\text { sosio, spiritual dan kultural }\end{array}$ & & & & \\
\hline & $\begin{array}{l}\text { Membaca rencana keperawatan yang } \\
\text { telah ditetapkan kepala shift }\end{array}$ & & & & \\
\hline & $\begin{array}{l}\text { Melakukan tindakan keperawatan } \\
\text { sesuai SPO berdasarkan rencana } \\
\text { keperawatan }\end{array}$ & & & & \\
\hline & $\begin{array}{l}\text { Melakukan evaluasi terhadap tindakan } \\
\text { yang telah dilakukan dan } \\
\text { mendokumentasikan pada format yang } \\
\text { tersedia }\end{array}$ & & & & \\
\hline & $\begin{array}{l}\text { Mengelola klien di bawah tanggung } \\
\text { jawabnya sesuai pembagian tugas dari } \\
\text { kepala shift }\end{array}$ & & & & \\
\hline & $\begin{array}{l}\text { Melaksanakan tugas delegasi dari } \\
\text { kepala shift }\end{array}$ & & & & \\
\hline & $\begin{array}{l}\text { Mengkomunikasikan permasalahan } \\
\text { yang ditemukan dengan kepala shift }\end{array}$ & & & & \\
\hline & $\begin{array}{l}\text { Berperan serta dalam pendidikan } \\
\text { kesehatan kepada klien/keluarga }\end{array}$ & & & & \\
\hline & $\begin{array}{l}\text { Memberikan resep dan menerima obat } \\
\text { dari keluarga klien yang menjadi } \\
\text { tanggungjawabnya dengan } \\
\text { berkoordinasi dengan kepala shift }\end{array}$ & & & & \\
\hline & Perawat mengingatkan klien, keluarga & & & & \\
\hline
\end{tabular}




\begin{tabular}{|c|c|c|c|}
\hline & $\begin{array}{l}\text { atau pengunjung apabila sudah masuk } \\
\text { waktu sholat }\end{array}$ & & \\
\hline & $\begin{array}{l}\text { Perawat membantu, membimbing serta } \\
\text { mendampingi klien dalam } \\
\text { melaksanakan sholat }\end{array}$ & & \\
\hline 2. & \multicolumn{3}{|l|}{ Perilaku Kerja (berdasarkan caring) } \\
\hline & $\begin{array}{l}\text { Komunikasi } \\
\text { Perawat dapat menunjukkan } \\
\text { komunikasi terapeutik dengan kontak } \\
\text { mata, bahasa tubuh, dan nada suara } \\
\text { yang menunjukkan perhatian kepada } \\
\text { klien }\end{array}$ & \multirow{8}{*}{60} & \multirow{8}{*}{100} \\
\hline & $\begin{array}{l}\text { Optimisme } \\
\text { Perawat menunjukkan optimisme dan } \\
\text { harapan terhadap kondisi klien dengan } \\
\text { meyakinkan klien untuk menerima } \\
\text { keadaan }\end{array}$ & & \\
\hline & $\begin{array}{l}\text { Kerjasama } \\
\text { Perawat bekerja sama dengan klien } \\
\text { dalam melakukan asuhan keperawatan, } \\
\text { ditunjukkan dengan klien bersedia dan } \\
\text { menerima untuk dirawat oleh perawat } \\
\text { tersebut }\end{array}$ & & \\
\hline & $\begin{array}{l}\text { Koordinasi } \\
\text { Perawat mampu berkoordinasi dengan } \\
\text { kepala shift dan anggota tim nya, } \\
\text { ditunjukkan dengan tidak ada konflik } \\
\text { secara internal }\end{array}$ & & \\
\hline & $\begin{array}{l}\text { Tanggap } \\
\text { Perawat tanggap dan cepat merespon } \\
\text { permasalahan dan kebutuhan klien } \\
\text { dalam asuhan keperawatan }\end{array}$ & & \\
\hline & $\begin{array}{l}\text { Keterbukaan } \\
\text { Perawat mampu berbagi pengalaman } \\
\text { dalam bentuk pendidikan kesehatan } \\
\text { (penyuluhan) kepada klien dan keluarga } \\
\text { sebagai upaya peningkatan kesehatan } \\
\text { klien }\end{array}$ & & \\
\hline & $\begin{array}{l}\text { Etika } \\
\text { Perawat memberikan informed consent } \\
\text { dan menjaga privasi klien setiap akan } \\
\text { melakukan tindakan keperawatan dan } \\
\text { medis }\end{array}$ & & \\
\hline & $\begin{array}{l}\text { Motivasi } \\
\text { Perawat mampu memberikan semangat } \\
\text { kepada klien untuk mengikuti proses }\end{array}$ & & \\
\hline
\end{tabular}




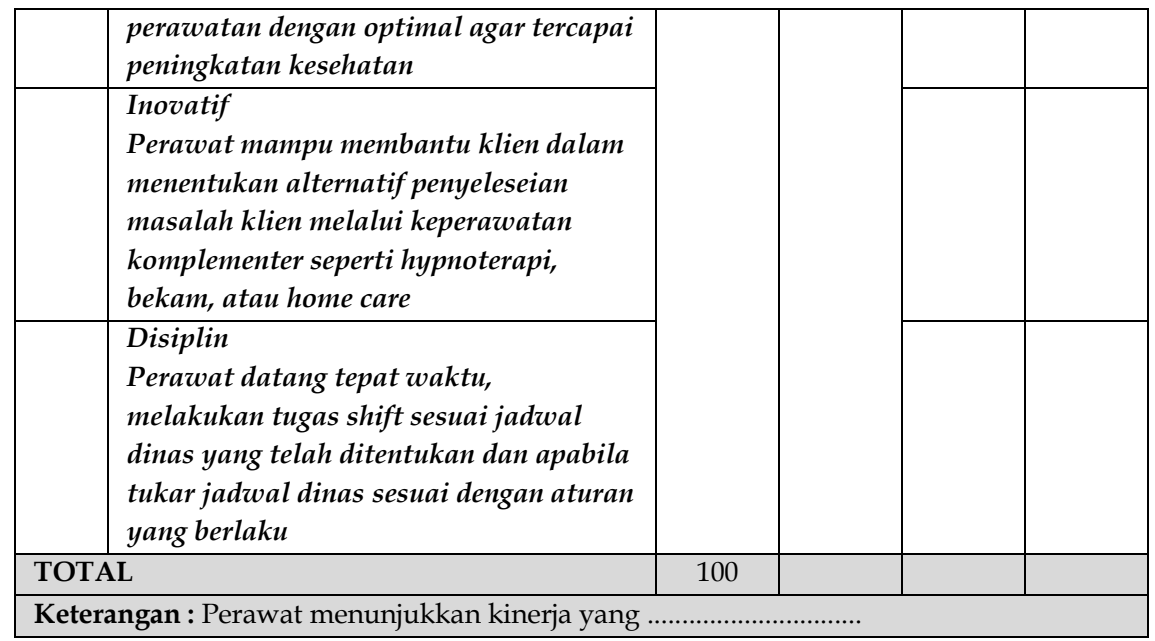

Uraian/ tanggapan perawat yang dinilai :

Komentar pejabat penilai atas tanggapan perawat yang dinilai :

Bojonegoro,

Perawat yang Dinilai

Pejabat Penilai

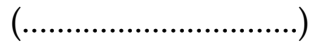

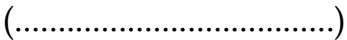


Rencana Tindak lanjut dan Pengembangan : SDM Keperawatan

1.

2.

3.

Keterangan

Sangat baik/Istimewa : $>95$

Baik $: 86 \mathrm{~s} / \mathrm{d} 95$

Cukup $: 66 \mathrm{~s} / \mathrm{d} 85$

Kurang $: 51 \mathrm{~s} / \mathrm{d} 65$

Sangat Kurang

$:<50$ 